Article

\title{
Impact of Pandemic COVID-19 on Air Quality at a Combustion Plant and Adjacent Areas
}

\author{
Robert Cichowicz $^{1, *(\mathbb{D})}$ and Jacek Wiśniewski ${ }^{2}$
}

1 Faculty of Civil Engineering, Architecture and Environmental Engineering, Lodz University of Technology, Al. Politechniki 6, 90-924 Lodz, Poland

2 Waterwork and Sewage System Plant Co., Ltd., Sanitariuszek 66, 91-867 Lodz, Poland; jacek_wisniewski@zwik.lodz.pl

* Correspondence: robert.cichowicz@p.lodz.pl

check for updates

Citation: Cichowicz, R.; Wiśniewski, J. Impact of Pandemic COVID-19 on Air Quality at a Combustion Plant and Adjacent Areas. Sustainability 2022, 14, 2594. https://doi.org/ $10.3390 /$ su14052594

Academic Editor: Diego Pablo Ruiz Padillo

Received: 19 January 2022

Accepted: 18 February 2022

Published: 23 February 2022

Publisher's Note: MDPI stays neutral with regard to jurisdictional claims in published maps and institutional affiliations.

Copyright: (C) 2022 by the authors. Licensee MDPI, Basel, Switzerland. This article is an open access article distributed under the terms and conditions of the Creative Commons Attribution (CC BY) license (https:/ / creativecommons.org/licenses/by/ $4.0 /)$.

\begin{abstract}
Following the emergence of the infectious disease COVID-19, caused by the coronavirus SARS-Cov-2, the WHO (World Health Organization) declared a pandemic in March 2020. The pandemic has affected people's health, social behaviour, and the economy around the world. It has also had an indirect impact on the environment, including atmospheric air quality, related to changes in the levels of pollutant emissions and the amounts of greenhouse gases released into the atmosphere. The observed changes have, in part, been a consequence of restrictions on human movement, which has translated into an increase in water consumption, and consequently into an increase in the volume of wastewater. As a result, a new type of incoming load has appeared in sewage treatment plants. Municipal sewage sludge (MSS) is a waste product from the wastewater treatment process, containing substances that are hazardous to both the environment and humans (bacteria, pathogens, viruses). To dispose of these contaminants, MSS is thermally processed in specially designed installations. Thermal recycling technology is based on a fluidized bed, in which MSS is rapidly transformed at a temperature of at least $750{ }^{\circ} \mathrm{C}$. Organic compounds are oxidized, gasified, and combusted. The exhaust fumes are emitted into the atmosphere. They also carry a load of pollutants, which can affect the air quality both on site and in the surroundings of the treatment plant. This paper presents measurements of air pollutant emissions and pollutant concentrations provided by the Group Sewage Treatment Plant in Łódź Itd. Łódź is a city located in Poland, in central Eastern Europe. The research covers the area of the wastewater treatment plant and its immediate surroundings within a radius of about $1.5 \mathrm{~km}$. The data show the influence of the pandemic restrictions on the concentrations of gaseous substances, bacteria, fungi, and particulate matter on the state of air quality. Increased emissions of $\mathrm{NOx}$ (by 86\%), PM10 (by $50 \%$ ), $\mathrm{HCl}$ (by 37\%), and SO2 (by 16\%) were observed compared to the pre-COVID-19 period.
\end{abstract}

Keywords: dispersion; pollution; sewage sludge; incineration; emission

\section{Introduction}

The sewage treatment process generates municipal sewage sludge (MSS), as well as other types of waste [1]. The properties of MSS, including high hydration, a significant share of organic substances, and high content of nitrogen, magnesium, and phosphorus compounds, make it attractive for agricultural use [2]. However, such use is limited or even made impossible by the high rotability of MSS, its content of heavy metals (such as cadmium, lead, and mercury), and the content of pathogenic organisms, such as pathogenic bacteria, viruses, and fungi [3], due to which MSS poses a great threat to the natural environment. Therefore, thermal treatment, also known as incineration, seems to be a rational solution for reducing the amount of MSS [4]. Thermal treatment can be used to manage various types of waste, reducing the amount of waste and its negative impact on the environment. It is one of the most effective ways of significantly reducing the amount of 
MMS. However, the process of thermal waste conversion produces flue gases that contain pollutants and greenhouse gases, as well as post-process wastes such as slag, ash, and dust [5-7].

The increasing scale of the problem is shown by the fact that there are over 2000 thermal waste treatment installations in operation in the world, including about 1200 in Japan alone. In Europe, there are about 500 installations for thermal waste treatment, including about 20 in Poland. Of these, 11 are mono-incineration plants for the treatment of MSS, located in the largest municipal sewage treatment plants. The largest centers of this type in Poland are in Warsaw, Kraków, Łódź, Gdańsk, Gdynia, and Bydgoszcz. The technologies used in these plants are based on fluidized bed technology (in seven plants) or grate technology (in the other four plants). Table 1 shows the performance of some of the largest installations [8].

Table 1. Efficiency of the main Polish mono-incineration plants.

\begin{tabular}{cccc}
\hline City & Efficiency $[\mathbf{M g} / \mathbf{d}]$ & City & Efficiency $[\mathbf{M g} / \mathbf{d}]$ \\
\hline Warszawa & 566 & Gdynia & 110 \\
Kraków & 282 & Gdańsk & 90 \\
Łódź & 264 & Bydgoszcz & 30 \\
\hline
\end{tabular}

In Germany, sewage sludge is incinerated at 26 installations and co-incinerated in power plants, cement plants, and municipal waste incineration plants. The main centres are in Berlin, Hamburg, and Munich. German municipal sewage sludge co-incineration power plants are located in Farge-Bremen, Braunsbedra, and Saarberg-Karlsruhe. About 55\% of the sewage sludge produced in Germany is disposed of by thermal treatment [9]. For comparison, in Denmark 40\% and in France 30\% of municipal sewage sludge is disposed of thermally. In Japan, more than half of the sewage sludge produced is co-incinerated with municipal waste. In the USA, about $30 \%$ of municipal sewage sludge is thermally transformed (major centres include the Essex County Resource Recovery Facility in Newark, the Lee County Solid Waste Resource Recovery Facility in Fort Myers, and the Montgomery County Resource Recovery Facility in Dickerson) [10]. There are also other European power plants that co-incinerate sewage sludge, such as Hamweg and Boresle-12 in the Netherlands, Frantschach, Lenzig, Linz in Austria, and Longannet in the UK [11].

Fermentation processes biologically stabilize the sludge from wastewater treatment processes and reduce its volume. Stabilization can take place under aerobic or anaerobic conditions. Mesophilic, anaerobic fermentation produces biogas consisting mainly of methane and carbon dioxide; whereas thermophilic, aerobic fermentation produces carbon dioxide and ammonia [12]. Municipal sewage sludge contains a considerable amount of moisture, usually in the range of 72-98\% [13]. Thermal treatment causes a large reduction in the volume of MMS (by up to 90\%), depending on the technology used (e.g., drying). At the same time, it reduces the content of organic substances, which reduces the calorific value of MMS by up to 50\% [14]. Sewage sludge also contains significant amounts of nitrogen, heavy metals [15,16], bacteria, and other pathogens [12,17]. Thermal treatment of municipal sewage sludge causes the emission of pollutants, e.g., heavy metals, dioxins, furans, dust, $\mathrm{NOx}, \mathrm{SO}_{2}, \mathrm{HCl}$, and $\mathrm{HF}$ [13]. The limit values for pollutant concentrations specified in Directive 2010/75/EC of the European Parliament and of the Council, which provides the limit values for average daily emissions, are given in Table 2.

Using the exhaust gas treatment processes, emission levels for $\mathrm{NOx}$ can be reduced by over $90 \%$. Emissions of most heavy metals can be reduced by over $95 \%$, and emissions of dust by up to $99.9 \%$ [18]. These reductions depend, of course, on the type of flue gas cleaning technology used. There are two main methods of flue gas cleaning: the dry method and the wet method. In the dry method, dust-like reagents are injected into the flue gas stream and then dedusted on filter fabrics. In the wet method, the flue gas stream is passed through a scrubber with a reagent solution. 
Table 2. Concentration limits for pollutants according to European Parliament Directive (2010/75/EC).

\begin{tabular}{cc}
\hline Contamination & Concentration Limits of Pollutants $\left[\mathbf{m g} / \mathbf{N m}^{\mathbf{3}}\right]$ \\
\hline Dust PM10 & 10 \\
Total Organic Carbon TOC & 10 \\
Hydrogen chloride HCl & 10 \\
Hydrogen fluoride HF & 1 \\
Sulphur dioxide $\mathrm{SO}_{2}$ & 50 \\
Nitrogen oxides $\mathrm{NO}_{x}$ & $200 *$ \\
\hline
\end{tabular}

* $400 \mathrm{mg} / \mathrm{Nm} 3$ for existing waste incineration plants with a nominal capacity greater than 6 tons per hour or less.

Due to the technical and technological limitations of flue gas cleaning installations (the efficiency of filtration systems is about $99.9 \%$ ), some pollutants are released into the environment. The formation of chemicals, bacteria, and fungi during storage, drying, and combustion of municipal sewage sludge may have a negative impact on staff operating the facility and local residents [13,19-21]. When planning the location of thermal waste treatment plants, relevant institutions should consider not only technical and technological aspects, but also the opinions of local communities. Due to widespread concerns about air quality and pollutants in the vicinity of treatment plants, local public opinion usually opposes new installations [22].

The related literature concerns mainly the influence of compounds such as dioxins (PCDD/F), polycyclic aromatic hydrocarbons (TCDD), and heavy metals $(\mathrm{Cr}, \mathrm{Cd}, \mathrm{Ni}, \mathrm{Pb})$ on sewage treatment plants and plant personnel. These substances are generated during the normal operation of municipal waste incineration systems $[23,24]$. The literature also includes analyses of the effectiveness of atmospheric air purification processes and the concentrations of pollutants contained in exhaust gases $[16,25,26]$, including emissions from drying municipal sewage sludge [27]. However, no previous analyses have investigated the impact of thermal processing of MSS on air quality in the vicinity of a sewage treatment plant. Such installations are usually located in large wastewater treatment plants and can serve populations of around a million.

\section{Materials and Methods}

\subsection{Study Area}

Łódź is located in central Poland, East-Central Europe. The Sewage Treatment Plant of Łódź (GOŚ) Ltd. is a typical mechanical and biological treatment plant, with additional removal of biogenic compounds. The biological process is periodically supported by an iron coagulant and an external carbon source. The designed capacity of the sewage treatment plant is $1,026,260$ RLM. The average daily sewage inflow is $173,176 \mathrm{~m}^{3} / \mathrm{d}$. As a result of the wastewater treatment process, approx. $1380 \mathrm{~m}^{3} / \mathrm{d}$ of sludge is produced, which undergoes mesophilic fermentation. About $236 \mathrm{~m}^{3} / \mathrm{d}$ of stabilized dehydrated sludge is obtained. The newly created dewatered sludge is then directed to the Thermal Sludge Installation Plant, where two fluidized bed furnaces are installed, each with a capacity of approx. $4 \mathrm{MW}$. Within $24 \mathrm{~h}, 220 \mathrm{Mg}$ of sludge is thermally transformed. Figure 1 shows a diagram of the installation.

The analyzed Thermal Sludge Installation Plant (ITPO) consists of two independent technological lines. It comprises:

- $\quad$ sludge storage and transport systems

- preliminary drying systems

- two fluidized bed furnaces made in the Pyrofluid technology by Veolia Water Technologies

- flue gas heat recovery systems, including a fluidizing air heat exchanger, a recuperator, and a steam boiler for producing steam for drying the sludge

- exhaust gas treatment systems, including a multi-cyclone, a regent preparation system for exhaust gas treatment, and a bag filter

- supporting systems in the form of exhaust fans, chimneys, and a steam distribution system 


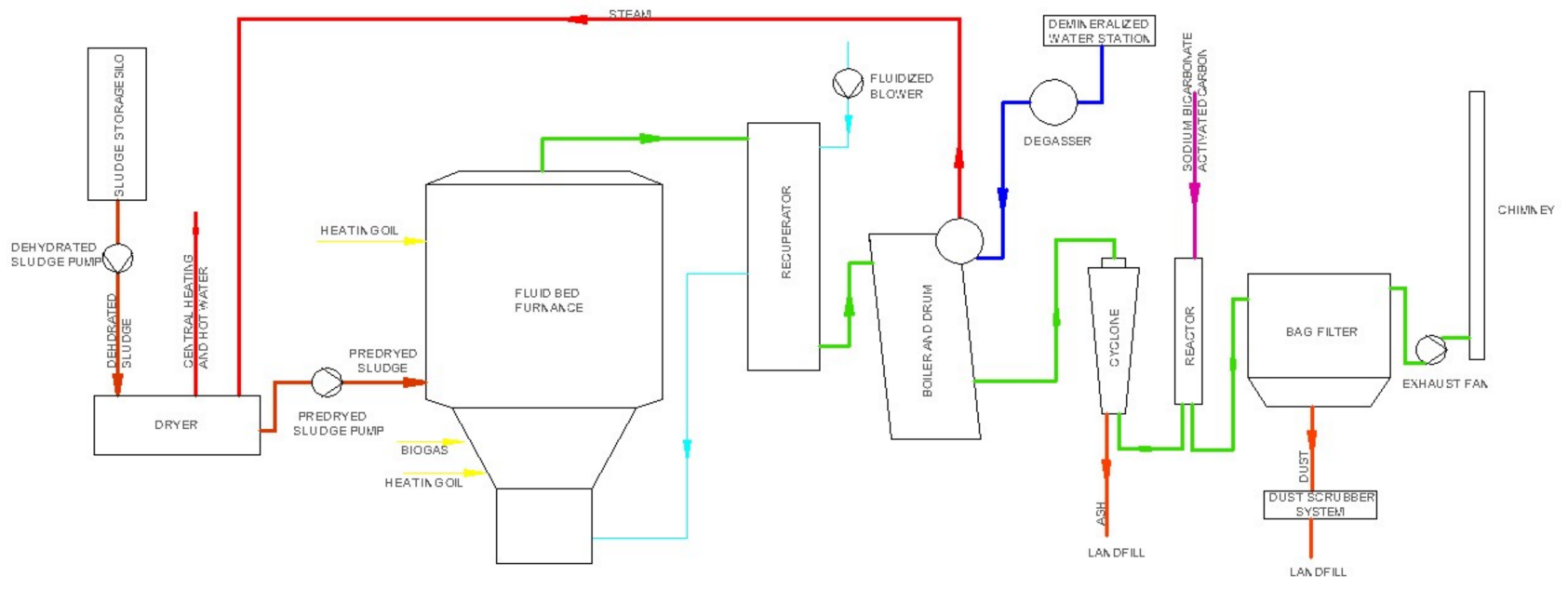

Figure 1. Thermal Sludge Installation Plant (ITPO).

The dehydrated sewage sludge is transported by screw conveyors to two storage silos with a capacity of $50 \mathrm{~m}^{3}$ each. For technical and technological reasons, part of the sludge may be stored temporarily in the warehouse yard, and is then subjected to management [28-30]. The sludge is pumped to disk dryers with diaphragm steam drying. The material is dried from about $20-24 \%$ dry matter to $30-32 \%$ dry matter. The energy for pre-drying is generated using saturated steam, which is recovered from burning the sludge. The pre-dried sludge is thermally transformed as a result of complex physico-chemical processes at a temperature of $750-850^{\circ} \mathrm{C}$. Each of the furnaces is designed for a thermal power of approx. $4 \mathrm{MW}$ and contains approx. 11 tons of quartz sand. The quartz sand creates a heat buffer for the variable nature of the sludge. In accordance with national regulations, the temperature in the post-combustion chamber must be at least $850{ }^{\circ} \mathrm{C}$, and the residence time of the exhaust gases must not be shorter than $2 \mathrm{~s}$. Thermal energy is extracted from the resulting exhaust gas and used to heat the fluidizing air and generate steam. The exhaust gas then goes to a two-stage dry method cleaning system, using activated carbon and sodium bicarbonate. A system is available for selective non-catalytic reduction of nitrogen oxides (NSCR) with the use of ammonia water solution. Research shows that sludge dehydrated on belt presses contains significant amounts of ammonia in the intermolecular water [31]. By feeding the dried sludge into the combustion chamber, the ammonia it contains significantly reduces nitrogen oxides. The NSCR installation is not used routinely, but is kept on standby.

To reduce the amounts of heavy metals and mercury in the exhaust gas, about $150-300 \mathrm{mg}$ of active carbon per $\mathrm{m}^{3}$ of flue gas is injected into the stream. To eliminate acid compounds contained in the exhaust gas such as $\mathrm{SO}_{2}, \mathrm{HCl}$, and $\mathrm{HF}$, ground sodium bicarbonate is also injected into the exhaust stream at a rate of approx. $43 \mathrm{~kg}$ per hour. Dedusting is performed in duocyclones, into which the flue gas flows tangentially to the circuit of the device. As the duocyclones slow down, the heaviest pollutants are discharged as ash. The flue gas stream is mixed with the reactants, activated carbon, and sodium bicarbonate. The mixture settles on the fabric of bag filters. The excess is automatically shaken off and evacuated from the installation in the form of dust. The dedusted and cleaned flue gases are directed into the atmosphere through two chimneys with internal diameters of $0.7 \mathrm{~m}$ and heights of $25 \mathrm{~m}$. The nominal exhaust gas temperature at the chimney outlet is approx. $170{ }^{\circ} \mathrm{C}$. The exhaust velocity is approx. $11 \mathrm{~m} / \mathrm{s}$. The concentration of oxygen in the exhaust gas is approx. $9 \%$.

\subsection{Municipal Sewage Sludge Subjected to Thermal Transformation}

The elemental composition of the sewage sludge produced at GOS is monitored constantly. Any change may affect both the combustion process and the emission of the 
resulting pollutants into the atmosphere. In particular, the carbon, hydrogen, and sulfur content is controlled, as well as the calorific value and heat of combustion. Analysis of the environmental impact of the thermal sludge treatment plants was carried out in the years 2012-2020, which were divided into three sub-periods. Period I covers the years 2012-2016. Period II covers the years 2017-2018. Period III covers the years 2019-2020, i.e., the COVID-19 pandemic. Tables 3 and 4 show the values of the main components affecting the combustion process in the third period.

Table 3. Main components and properties of sludge thermally transformed into ITPO in 2019.

\begin{tabular}{cccccc}
\hline Month & $\begin{array}{c}\text { Elemental } \\
\text { Analysis of } \\
\text { Sulfur-S [\%] }\end{array}$ & $\begin{array}{c}\text { Elemental } \\
\text { Analysis of } \\
\text { Carbon-C } \\
{[\%]}\end{array}$ & $\begin{array}{c}\text { Elemental } \\
\text { Analysis of } \\
\text { Hydrogen-H } \\
{[\%]}\end{array}$ & $\begin{array}{c}\text { Calorific } \\
\text { Value } \\
\text { [M]/kg] }\end{array}$ & $\begin{array}{c}\text { Heat of } \\
\text { Combustion } \\
\text { [M]/kg] }\end{array}$ \\
\hline January & 1.09 & 31.3 & 5.3 & 18.9 & 21.3 \\
February & 1.08 & 31.28 & 5.26 & 17.6 & 20.7 \\
March & 1.06 & 31.80 & 5.95 & 18.2 & 22.0 \\
April & 1.19 & 32.85 & 5.20 & 18.8 & 22.0 \\
May & 1.26 & 32.05 & 5.04 & 19.2 & 21.5 \\
June & 1.21 & 28.90 & 5.33 & 19.3 & 21.0 \\
July & 1.29 & 30.90 & 4.98 & 16.9 & 20.2 \\
August & 1.34 & 30.90 & 5.04 & 16.7 & 19.9 \\
September & 1.16 & 29.95 & 5.04 & 17.0 & 19.7 \\
October & 1.06 & 31.27 & 5.15 & 18.1 & 20.0 \\
November & 1.07 & 3.00 & 5.41 & 19.2 & 21.3 \\
December & 1.05 & 32.64 & 5.67 & & 22.4 \\
\hline
\end{tabular}

Table 4. Main components and properties of sludge thermally transformed into ITPO in 2020.

\begin{tabular}{cccccc}
\hline Month & $\begin{array}{c}\text { Elemental } \\
\text { Analysis of } \\
\text { Sulfur-S [\%] }\end{array}$ & $\begin{array}{c}\text { Elemental } \\
\text { Analysis of } \\
\text { Carbon-C } \\
{[\%]}\end{array}$ & $\begin{array}{c}\text { Elemental } \\
\text { Analysis of } \\
\text { Hydrogen-H } \\
{[\%]}\end{array}$ & $\begin{array}{c}\text { Calorific } \\
\text { Value } \\
\text { [M]/kg] }\end{array}$ & $\begin{array}{c}\text { Heat of } \\
\text { Combustion } \\
\text { [MJ/kg] }\end{array}$ \\
\hline January & 0.827 & 31.95 & 5.4 & 18.4 & 21.6 \\
February & 0.825 & 3.05 & 5.39 & 17.8 & 20.9 \\
March & 0.715 & 3.05 & 5.68 & 18.7 & 21.9 \\
April & 0.692 & 32.89 & 5.47 & 18.6 & 21.6 \\
May & 0.738 & 31.75 & 5.26 & 17.0 & 21.0 \\
June & 0.756 & 30.98 & 5.14 & 18.1 & 20.7 \\
July & 0.784 & 30.50 & 5.03 & 18.1 & 20.9 \\
August & 0.856 & 29.75 & 4.91 & 16.8 & 19.9 \\
September & 0.916 & 31.10 & 4.99 & 17.1 & 20.2 \\
October & 0.930 & 31.85 & 5.25 & 18.0 & 21.1 \\
November & 0.935 & 31.97 & 5.31 & 17.6 & 21.0 \\
December & 0.898 & 32.08 & 5.16 & 18.1 & 21.4 \\
\hline
\end{tabular}

As can be seen, the composition and properties of the sludge were stable. Slight changes did not exceed $1 \%$ (for hydrogen, carbon, calorific value, and heat of combustion). Only the amount of sulfur in the sludge decreased by approx. 30\% in 2020 compared to 2019 .

Elemental analysis was carried out by determining the total content of the element in the soil, and then heating the sample to a temperature of at least $1150{ }^{\circ} \mathrm{C}$ in an oxygencontaining gas stream. The elements bound in organic and inorganic bonds were converted into oxides. Evolution of the oxide was measured using infrared spectrometry. The opal value and the heat of combustion were determined in a calorimetric bomb using an isoperibolic calorimeter or a calorimeter with a static jacket. 


\subsection{Meteorological Conditions}

The Installation of Thermal Sludge Plants (ITPO) is located near the west-south-west (WSW) border of the city of Łódź. During all periods, pollutants spread in the air through fragments of the existing ventilation corridors towards the city centre. During Period I, westerly winds prevailed. The average annual temperature Period I ranged from $8.7-9.4{ }^{\circ} \mathrm{C}$, with the highest temperature reaching the maximum value of $350{ }^{\circ} \mathrm{C}$, and the lowest $-5^{\circ} \mathrm{C}$. The average amount of annual rainfall was in the range of $550-800 \mathrm{~mm}$, which made this area one of the driest in the country. There were $1900 \mathrm{~h}$ of sunlight. In Period II, westerly winds were also recorded, with an average temperature of $9.50^{\circ} \mathrm{C}$. The highest temperature was $33^{\circ} \mathrm{C}$ and the lowest $9^{\circ} \mathrm{C}$. The average annual rainfall was $600-650 \mathrm{~mm}$. There were $2000 \mathrm{~h}$ of sunlight. In Period III, the wind was again westerly. The average temperature was $10.2{ }^{\circ} \mathrm{C}$. The highest temperature was $28^{\circ} \mathrm{C}$, and the lowest $-4{ }^{\circ} \mathrm{C}$. The average annual rainfall was $600 \mathrm{~mm}$. There were $2000 \mathrm{~h}$ of sunlight [32]. Compared to 30-year data, the analyzed years were typical in terms of average annual temperatures and hours of sunlight. On the other hand, there was an anomaly for the annual total rainfall, which was $100 \%$ higher than during the comparison period. Figure $2 \mathrm{a}, \mathrm{b}$ show the wind roses for Periods II and III [33].

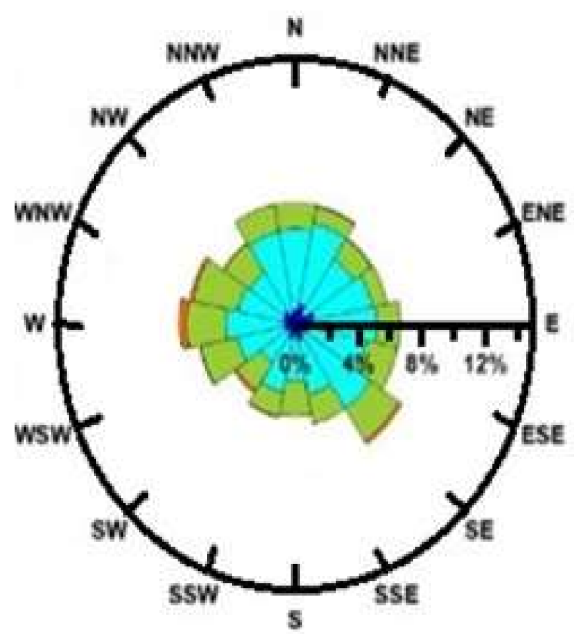

(a)

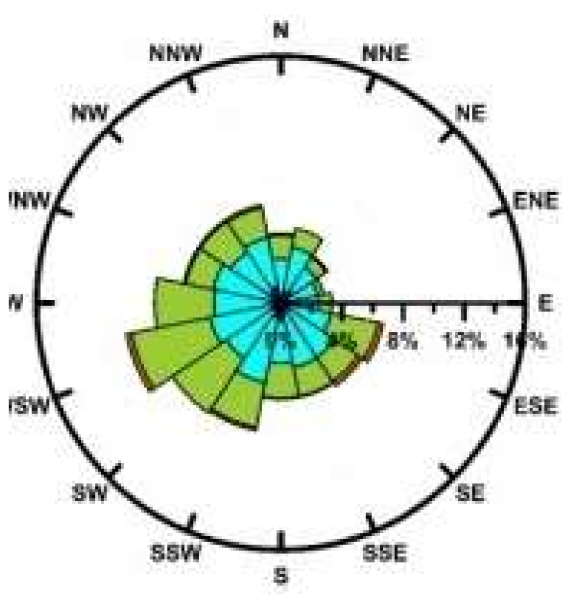

(b)

Figure 2. (a) Wind rose for Period II; [33]; (b) Wind rose for Period III [33].

\subsection{Change in the Characteristics of the Pollutants}

The data for Period I comprises air measurements collected at seven points in the main area of GOŚ and at eight points in the vicinity of the sewage treatment plant (Figure 3) [34-37]. The concentrations of air pollutants in the sewage treatment plant and in its vicinity were analyzed. In 2016, measurements of biological and physical factors were carried out within the ITPO building and in its close vicinity. The spread of pollutants from the emitters was modelled using the OPA03 application (Eko-Soft). The model was implemented with a grid of 11,000 receptors. After analyzing the results, the model could not be validated due to the low concentration of pollution caused by the ITPO compared to the total background air pollution near the treatment plant [38].

The purpose of the research was to compare the state of the ambient air before the pandemic to that during the pandemic. We examined how the character of pollutants changed over the three periods, and how the conditions of emission and spread of pollutants in the atmosphere changed, with a special focus on the site of the sewage treatment plant and the area around the thermal treatment plant. It was expected that the extraordinary circumstances of the pandemic would show relationships that previously had been hidden. This knowledge could be used to develop mathematical models and new systems for purifying atmospheric air. 


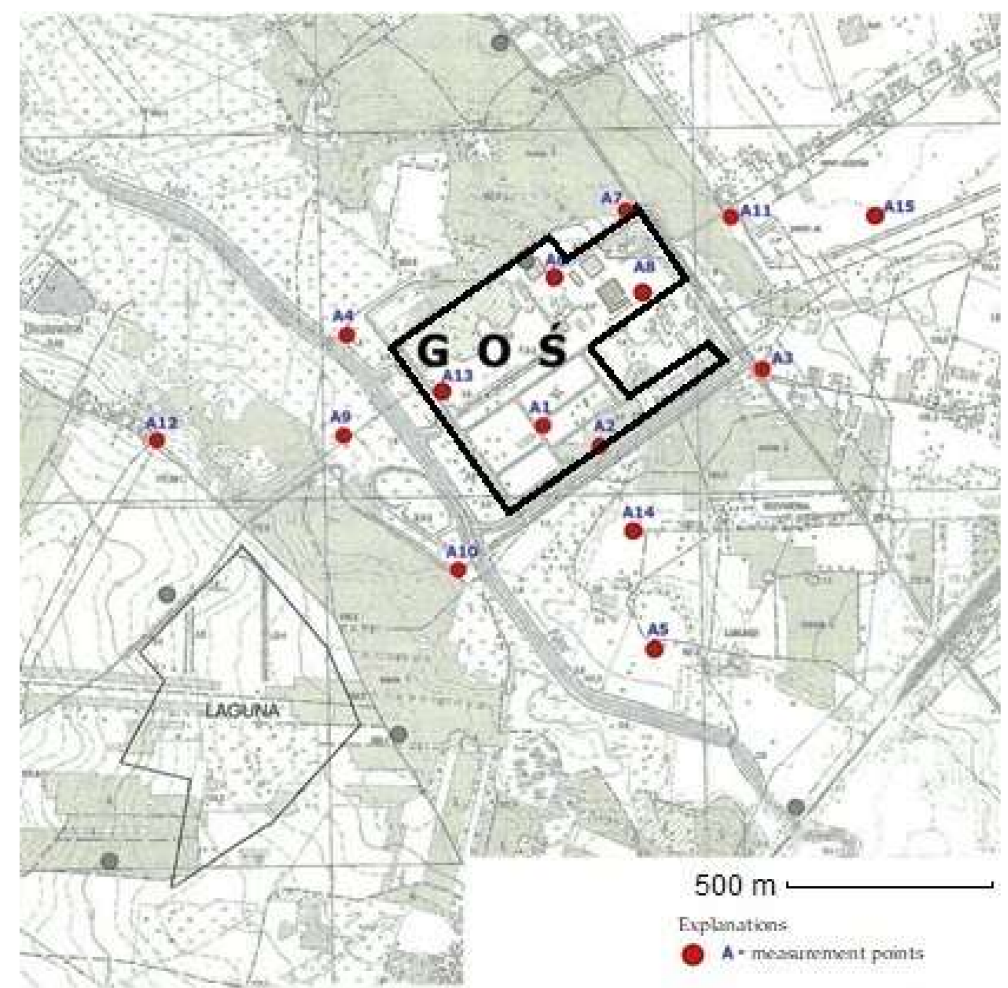

Figure 3. Map of measurement points.

\subsection{Measurements and Reference Methods}

To control the quality of ITPO exhaust gases, a continuous emission monitoring system (AMS) supplied by the French company Environment was installed on each of the lines (GOŚ). The AMS works in accordance with Directive 2000/76/EC of 4 December 2000 on the thermal treatment of waste. The scope of measurements and the measurement methods are presented in Table 5.

Table 5. Measurement scope and reference methods for substance measurements (GOŚ).

\begin{tabular}{|c|c|c|}
\hline Substance Name & Reference Methodology & Scope \\
\hline Dust PM10 & $\begin{array}{l}\text { Free technique modelled on the } \\
\text { gravimetric method }\end{array}$ & $0-60 \mathrm{mg} / \mathrm{Nm}^{3}$ \\
\hline $\begin{array}{c}\text { Nitrogen oxides } \\
\mathrm{NO}_{\mathrm{x}} \\
\text { in conversion to } \mathrm{NO}_{2} \text { ) }\end{array}$ & Radiation absorption IR & $0-500 \mathrm{mg} / \mathrm{Nm}^{3}$ \\
\hline $\begin{array}{l}\text { Hydrogen chloride } \\
\text { HCL }\end{array}$ & Radiation absorption IR & $0-120 \mathrm{mg} / \mathrm{Nm}^{3}$ \\
\hline $\begin{array}{l}\text { Carbon monoxide } \\
\mathrm{CO}\end{array}$ & Radiation absorption IR & $0-100 \mathrm{mg} / \mathrm{Nm}^{3}$ \\
\hline Total organic carbon COT & $\begin{array}{l}\text { Continuous flame ionization } \\
\text { detection technique (FID) }\end{array}$ & $0-50 \mathrm{mg} / \mathrm{Nm}^{3}$ \\
\hline $\begin{array}{l}\text { Hydrogen fluoride } \\
\text { HF }\end{array}$ & Radiation absorption IR & 0-15 mg/ $\mathrm{Nm}^{3}$ \\
\hline $\begin{array}{l}\text { Sulphur dioxide } \\
\qquad \mathrm{SO}_{2}\end{array}$ & Radiation absorption IR & 0-300 mg $/ \mathrm{Nm}^{3}$ \\
\hline
\end{tabular}

\subsubsection{Review of Measurement Techniques}

\section{- Radiation absorption IR}

The content of substance particles in the exhaust gases is measured in terms of the amount of radiation absorbed by the particles of a given compound. Electromagnetic 
radiation in the IR range has a frequency close to the vibration frequency of chemical bonds. Radiation passing through an exhaust gas is selectively absorbed, due to the excitation of vibrations in the chemical bonds. As a result, there is a series of sharp signals in the spectrum corresponding to the vibration of specific bonds. Since these values are tabulated, the IR absorption spectrum makes it possible to determine which bonds are present in the analyzed sample. After passing from the transmitter through the tested gas sample to the detector, the radiation beam is split and an interference image is created. The interference image is transformed into a spectrum with a specific wavelength. The recorded absorption spectrum is compared to to standard curves.

- Continuous flame ionization detection technique (FID)

The continuous flame ionization detection (FID) technique determines the intensity of the ionization current resulting from the combustion of organic compounds in a hydrogen flame. The intensity of this current depends on the number of carbon atoms from organic compounds burning in the flame of gas, as well as on the types of bonds in the organic compounds (straight or branched chains). The main advantage of the FID detector is that the signal strength depends on the presence of carbon in the organic compounds.

- The gravimetric method PCME QAL 181

It measures scattered forward light from a laser source. The measurement volume in the sensor probe is positioned in a representative location within the stack. The scattered light response is directly proportional to the dust concentration. The instrument optimizes its resolution and zero drift characteristics, providing accurate measurement below $0.1 \mathrm{mg} / \mathrm{m}^{3}$ as well as rugged operation in stacks where emissions exceed $300 \mathrm{mg} / \mathrm{m}^{3}$. The ProScatterTM Forward Scatter technique used in PCME QAL 181 collects the total cone of scattered light from particles in the measurement volume. This patented measurement method increases the signal to noise ratio, giving high stability even at low dust concentrations $\left(<0.1 \mathrm{mg} / \mathrm{m}^{3}\right)$.

The methodology for measuring the air pollutant emissions in the area of GOS and its outskirts was based on the techniques presented in Table 6.

Table 6. Methodology and scope of pollutant emission measurements in and around the GOŚ.

\begin{tabular}{|c|c|c|}
\hline Substance Name & $\begin{array}{l}\text { The Methodology } \\
\text { Applied }\end{array}$ & Scope \\
\hline $\begin{array}{l}\text { Sulphur dioxide } \\
\qquad \mathrm{SO}_{2}\end{array}$ & $\begin{array}{l}\text { The technique of ion } \\
\text { chromatography }\end{array}$ & $\begin{array}{c}5.2-13.0 \mathrm{mg} / \mathrm{m}^{3} \text { - gas samples taken } \\
\text { on filters coated with } \\
\text { sodium carbonate }\end{array}$ \\
\hline $\begin{array}{l}\text { Hydrogen sulphide } \\
\mathrm{H}_{2} \mathrm{~S}\end{array}$ & $\begin{array}{c}\text { Technique of } \\
\text { spectrophotometry Vis }\end{array}$ & $\begin{array}{l}0.00002-0.4 \mathrm{mg} / \mathrm{mL}-\text { gas samples } \\
\text { taken into absorbing solutions }\end{array}$ \\
\hline $\begin{array}{l}\text { Ammonia } \\
\mathrm{NH}_{3}\end{array}$ & $\begin{array}{l}\text { The technique of ion } \\
\text { chromatography }\end{array}$ & $\begin{array}{c}17.4-24.4 \mathrm{mg} / \mathrm{m}^{3} \text { _air samples } \\
\text { collected on tubes with a silica gel } \\
\text { sorbent }\end{array}$ \\
\hline $\begin{array}{l}\text { Methane } \\
\mathrm{CH}_{4}\end{array}$ & $\begin{array}{l}\text { The technique of infrared } \\
\text { spectrometry }\end{array}$ & $\begin{array}{c}150-150,000 \mathrm{mg} / \mathrm{m}^{3} \text { - air samples } \\
\text { taken into a plastic bag }\end{array}$ \\
\hline $\begin{array}{l}\text { Carbon dioxide } \\
\qquad \mathrm{CO}_{2}\end{array}$ & $\begin{array}{l}\text { The technique of infrared } \\
\text { spectrometry }\end{array}$ & $\begin{array}{c}500-200,000 \mathrm{mg} / \mathrm{m}^{3} \text { _air samples } \\
\text { taken into a plastic bag }\end{array}$ \\
\hline $\begin{array}{l}\text { Nitrogen dioxide } \\
\mathrm{NO}_{2}\end{array}$ & $\begin{array}{l}\text { The technique of ion } \\
\text { chromatography }\end{array}$ & $\begin{array}{c}0.04-5.0 \mathrm{mg} / \mathrm{m}^{3} \text { - air samples taken } \\
\text { on tubes with sorbent TEA_IMS }\end{array}$ \\
\hline $\begin{array}{l}\text { Nitric oxide } \\
\text { NO }\end{array}$ & $\begin{array}{l}\text { The technique of ion } \\
\text { chromatography }\end{array}$ & $\begin{array}{c}0.03-5.0 \mathrm{mg} / \mathrm{m}^{3} \text { - air samples taken } \\
\text { on tubes with sorbent TEA_IMS }\end{array}$ \\
\hline
\end{tabular}




\subsubsection{Overview of Measurement Techniques}

- Ion chromatography

Samples are collected by drawing air through active samplers. The active samplers contain sodium carbonate coated filters connected to personal sampling pumps. During sampling, the sulfur dioxide reacts with sodium carbonate to form sodium sulfite. The sulfite is extracted from the filter in the laboratory and oxidized to sulfate using hydrogen peroxide. The sulfate is analyzed by ion chromatography using a conductivity detector.

- Spectrophotometry Vis

Samples are collected by drawing workplace air through active samplers. The active samplers contain sodium carbonate coated filters connected to personal sampling pumps. During sampling, sulfur dioxide reacts with sodium carbonate forming sodium sulfite. The sulfite is extracted from the filter in the laboratory and oxidized to sulfate using hydrogen peroxide. The sulfate is analyzed by ion chromatography using a conductivity detector.

- Infrared spectrometry

Infra-red (IR) light has a length similar to chemical bonds. As it passes through a sample of the tested substance, IR radiation is selectively absorbed due to the excitation of vibrations of chemical bonds with a length corresponding to the length of the absorbed wave. As a result, there are a number of sharp signals in the spectrum corresponding to the vibrations of specific bonds. Because these values are tabulated, the IR spectrum makes it possible to determine which bonds are present in the analyzed sample.

\subsection{Analysis of Pollution}

Analysis of the pollutants associated with the operation of the installation showed that the emissions had little effect on air quality in the sewage treatment plant. The share of the total concentration of pollutants is presented in Table 7 and did not exceed the permissible average annual concentrations for these substances specified in Directive 2008/50/EC.

Table 7. Concentrations of pollutants from ITPO in 2012-2015 (Cichowicz, Stelgowski 2019).

\begin{tabular}{ccc}
\hline Contamination & $\begin{array}{c}\text { The Concentration of } \\
\text { Pollutants } \mu \mathrm{g} / \mathrm{m}^{\mathbf{3}}\end{array}$ & $\begin{array}{c}\text { The Degree of Concentration } \\
\text { of Pollutants Compared } \\
\text { to Directive 2008/50/EC } \\
\%\end{array}$ \\
\hline $\mathrm{NO}_{\mathrm{x}}$ & 0.300 & 0.75 \\
$\mathrm{SO}_{2}$ & 0.800 & 4.00 \\
$\mathrm{PM} 10$ & 0.020 & 0.05 \\
$\mathrm{HCl}$ & 0.007 & 0.07 \\
\hline
\end{tabular}

Numerical analysis taking into account nominal conditions did not show any differences compared to the results obtained under real conditions. The highest annual concentration of air pollutants in the sewage treatment plant were lower by $0.02 \mu \mathrm{g} / \mathrm{m}^{3}$ for $\mathrm{NO}_{\mathrm{x}}, 0.05 \mu \mathrm{g} / \mathrm{m}^{3}$ for $\mathrm{SO}_{2}, 0.002 \mu \mathrm{g} / \mathrm{m}^{3}$ for PM10, and $0.0005 \mu \mathrm{g} / \mathrm{m}^{3}$ for $\mathrm{HCl}$. The experimental measurements proved that the ITPO has no influence on the concentration of air pollutants in GOŚ. After checking the background pollution in windward locations, it was found that the pollution levels corresponded to that on the ITPO site.

The only exception was in the case of $\mathrm{NH}_{3}$. The concentration of $\mathrm{NH}_{3}$ in the vicinity of the thermal conversion installation was almost three times higher than the levels recorded at other measurement points. In 2014, they were eight times higher than the background concentration. This was related to the large amount of $\mathrm{NH}_{3}$ contained in the dehydrated sludge subjected to the drying process and temporarily stored in the square. Leaks in the pre-drying system caused the emission of $\mathrm{NH}_{3}$ into the atmosphere.

By comparing the concentrations of biological agents determined at the ITPO with background concentrations, we calculated the ratio as below 0.5 . This is an overall value, 
without specifying the species of bacteria or fungi. It can be concluded that neither the drying process nor temporary storage had an influence on biological risk. The total amount of bacteria at this location did not exceed $1000 \mathrm{cfu} / \mathrm{m}^{3}$. The total amount of fungi did not exceed $3300 \mathrm{cfu} / \mathrm{m}^{3}$. These values are higher than at other studied sewage treatment plants [39].

Further analyses of air quality were performed for Periods II and III, covering the years 2017-2020. The analysis also included concentrations of chemical substances $\left(\mathrm{CO}, \mathrm{CO}_{2}\right.$, $\mathrm{NO}_{\mathrm{x}}, \mathrm{SO}_{2}, \mathrm{NH}_{3}$ ), physical factors (dust, thermal energy) and biological factors (bacteria, fungi). The data were collected by the automatic measurement system for flue gas emissions at the ITPO (Table 3) and during studies on emissions of air pollutants and harmful biological agents ordered by the group Sewage Treatment Plant in Łódź (Table 4). Samples of air for microbiological tests were collected in accordance with the Research Procedure KJI-5.7-21 Pobieranie próbek powietrza do badań mikrobiologicznych (Collecting air samples for microbiological research), based on the PN-EN 13098:2007 standard. The impact method was used for quantitative and qualitative determination of bacteria and fungi. An Impaktor MAS 100 NT [40] and anemometer Kestrel [41] were used with suitable substrates.

The research was carried out in accordance with the following procedures: KJ-I-5.421M version 09 of 25 February 2019, Mikrobiologiczne badanie powietrza. Oznaczanie bakterii w powietrzu wg. norm (Microbiological air testing. Determination of bacteria in the air in accordance with standards) [42,43] and KJ-I-5.4-22M version 07 of 25 February 2019, Mikrobiologiczne badanie powietrza. Oznaczanie liczby grzybów mikroskopowych w powietrzu wg norm (Microbiological air testing. The numbers of microscope fungi in the air were determined in accordance with standards $[40,44]$. The area of analysis included the site of the plant (41.3 ha), together with the limited usage zone (a legally designated area influenced by a sewage treatment plant). The area of limited impact is established under the Prawo Ochrony Środowiska (Law on Environmental Protection) of 27 April 2007 and by an act of local law [45]. In relation to the character of the plant, the zone has influence on the quality of air. In this zone, the accepted air quality standards may be exceeded.

The relationships between the concentration of air pollution around the ITPO and the background concentrations in other locations were determined. Figure 4 presents a map of the basic zone, together with the area of limited usage. The measurement points are indicated.

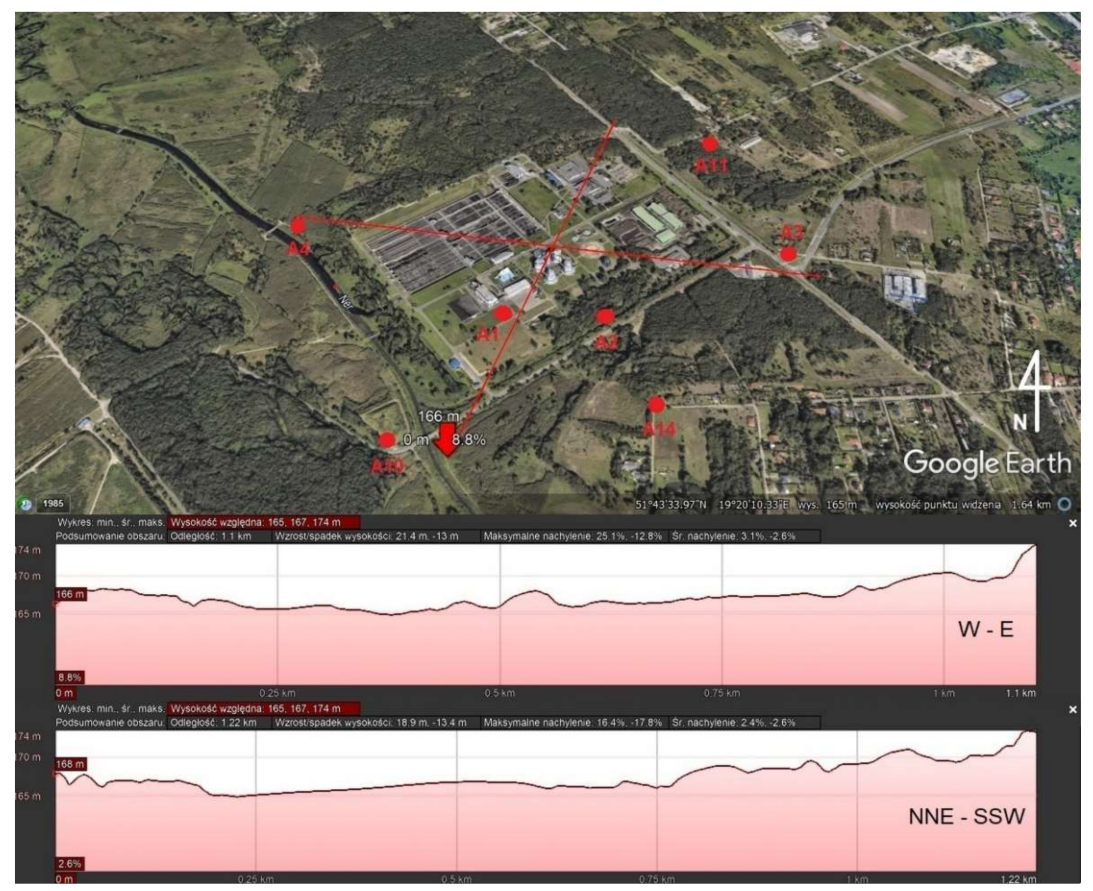

Figure 4. Map of GOŚ with the analyzed measurement points. The line between points A4 and A3 represents the terrain elevation profile from $\mathrm{W}-\mathrm{E}$. The line between A10 and A11 represents the terrain elevation profile from SSW-NNE. 
The tallest technological buildings located on the site of the plant are fermentation chambers. They are $30 \mathrm{~m}$ above ground level. Other elements of the technological structure do not exceed $10 \mathrm{~m}$ in height. Some elements are dug approx. $7 \mathrm{~m}$ deep into the ground.

From the north and the south, the plant is surrounded by forest. A treated sewage receiver, the Ner river, and another forest are located to the west. On the east side, the plant borders a district road and, further on, investment areas and an express route.

\subsection{Influence of the Pandemic on Changes in the Level of Air Pollution}

To determine the influence of pandemics on changes in the levels of atmospheric air pollution, we next studied Period III, the years 2019-2020. The aim was to compare data gathered during the period of lockdown with the preceding periods. The study was ordered by the sewage treatment plant itself, and was compiled during periodical experimental measurements of air quality in the plant area and its surroundings. Two measurement points were located within the limits of GOŚ. The other six were located in its vicinity [37]. The data were collected by an automatic measurement system for flue gas emissions installed at the ITPO. The results indicated that the level of pollution did not increase during the pandemic period. The concentrations of pollution did not exceed the limits on emissions into the air from medium combustion plants set by the European Parliament and the Council Directive 2015/2193 of 25 November 2015. The acceptable values are given in Table 8.

Table 8. Emission standards for combustion plants according to Directive (2015/2193/EC).

\begin{tabular}{|c|c|c|c|c|}
\hline \multirow{3}{*}{ No. } & \multirow{3}{*}{$\begin{array}{c}\text { Substance } \\
\text { Name }\end{array}$} & \multicolumn{3}{|c|}{$\begin{array}{l}\text { Emission Standards in } \mathrm{mg} / \mathrm{m}^{3}{ }_{\mathrm{u}} \text {, with } 11 \% \text { Oxygen RATE } \\
\text { in Exhaust Gas }\end{array}$} \\
\hline & & \multirow{2}{*}{ Daily Average } & \multicolumn{2}{|c|}{ 30-min Average } \\
\hline & & & A & B \\
\hline 1 & dust PM10 & 10 & 30 & 10 \\
\hline 2 & COT & 10 & 20 & 10 \\
\hline 3 & $\mathrm{HCl}$ & 10 & 60 & 10 \\
\hline 4 & $\mathrm{HF}$ & 1 & 4 & 2 \\
\hline 5 & $\mathrm{SO}_{2}$ & 50 & 200 & 50 \\
\hline 6 & $\mathrm{CO}$ & 50 & 100 & 150 \\
\hline 7 & $\mathrm{NO}_{\mathrm{x}}$ & 200 & 400 & 200 \\
\hline
\end{tabular}

The concentrations of chemical substances $\left(\mathrm{CO}, \mathrm{TOC}, \mathrm{NO}_{\mathrm{x}}, \mathrm{SO}_{2}, \mathrm{HCl}, \mathrm{HF}\right)$ and physical factors (PM10 dust) remained at the same level. The concentrations are presented in Table 9.

Table 9. Concentrations of pollution compared to limits set in Directive (2015/2193/CE).

\begin{tabular}{cc} 
Pollution & $\begin{array}{c}\text { Degree of Concentration of Pollution Compared to the } \\
\text { Standards of the European Parliament } \\
\text { Council Directive } 2015 / 2193 \text { of } 25 \text { November } 2015 \text { r. } \\
\%\end{array}$ \\
\hline $\mathrm{SO}_{2}$ & 74 \\
$\mathrm{NO}_{\mathrm{x}}$ & 16 \\
$\mathrm{HCl}$ & 21 \\
$\mathrm{COT}$ & 6 \\
$\mathrm{PM} 10$ & 14 \\
\hline
\end{tabular}

In 2019 , the average concentration of $\mathrm{SO}_{2}$ was $41.4 \mathrm{mg} / \mathrm{m}^{3}$; the standard is $50 \mathrm{mg} / \mathrm{m}^{3}$. The average concentration of $\mathrm{NO}_{x}$ was $30.8 \mathrm{mg} / \mathrm{m}^{3}$; the standard is $200 \mathrm{mg} / \mathrm{m}^{3}$. The concentration of dust was $2.1 \mathrm{mg} / \mathrm{m}^{3}$; the standard is $10 \mathrm{mg} / \mathrm{m}^{3}$. In 2020 , the concentration of $\mathrm{SO}_{2}$ was $32.6 \mathrm{mg} / \mathrm{m}^{3}$, the concentration of $\mathrm{NO}_{x}$ was $18.3 \mathrm{mg} / \mathrm{m}^{3}$, and the concentration of dust was $2.16 \mathrm{mg} / \mathrm{m}^{3}$. The significant reduction in pollution (in the case of $\mathrm{SO}_{2}$ by $21 \%$, 
in the case of $\mathrm{NO}_{x}$ by $40 \%$ ) could have been caused by changes in the structure of the sludge. Period III was characterized by the peak of COVID-19 infections, by lockdowns, and by changes in the functioning of large urban centres (less traffic, longer periods of staying at home, significant increases in the numbers of patients in medical centres).

\section{Results}

Figures 5-7 show the relationship between the content of elemental elements in the sediment and the emission of pollutants from the emitter. Data from the third period, which was the most characteristic of the pandemic period, are summarized.

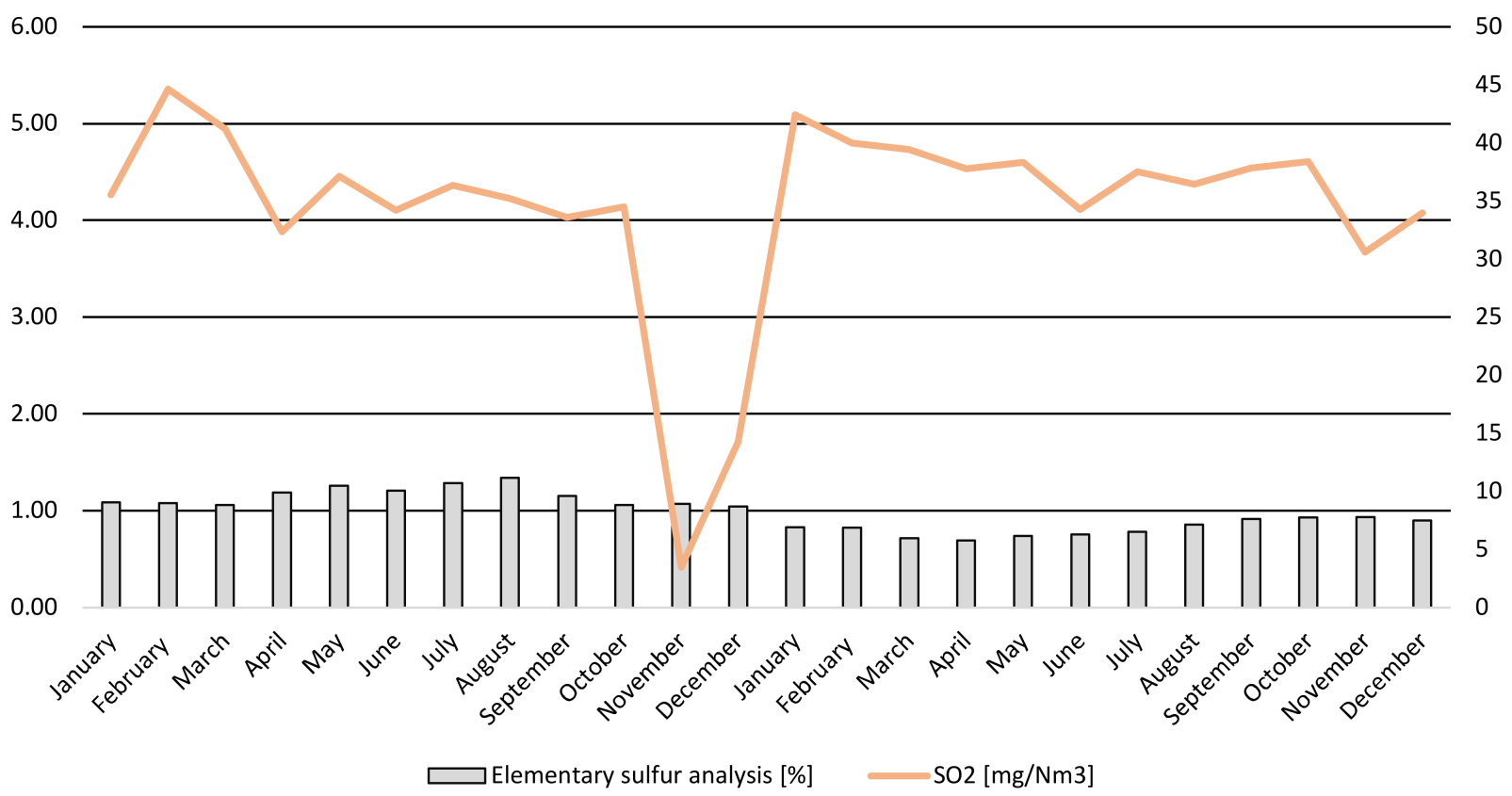

Figure 5. Relationship between sulfur content in the sediment and the emission of sulfur dioxide.

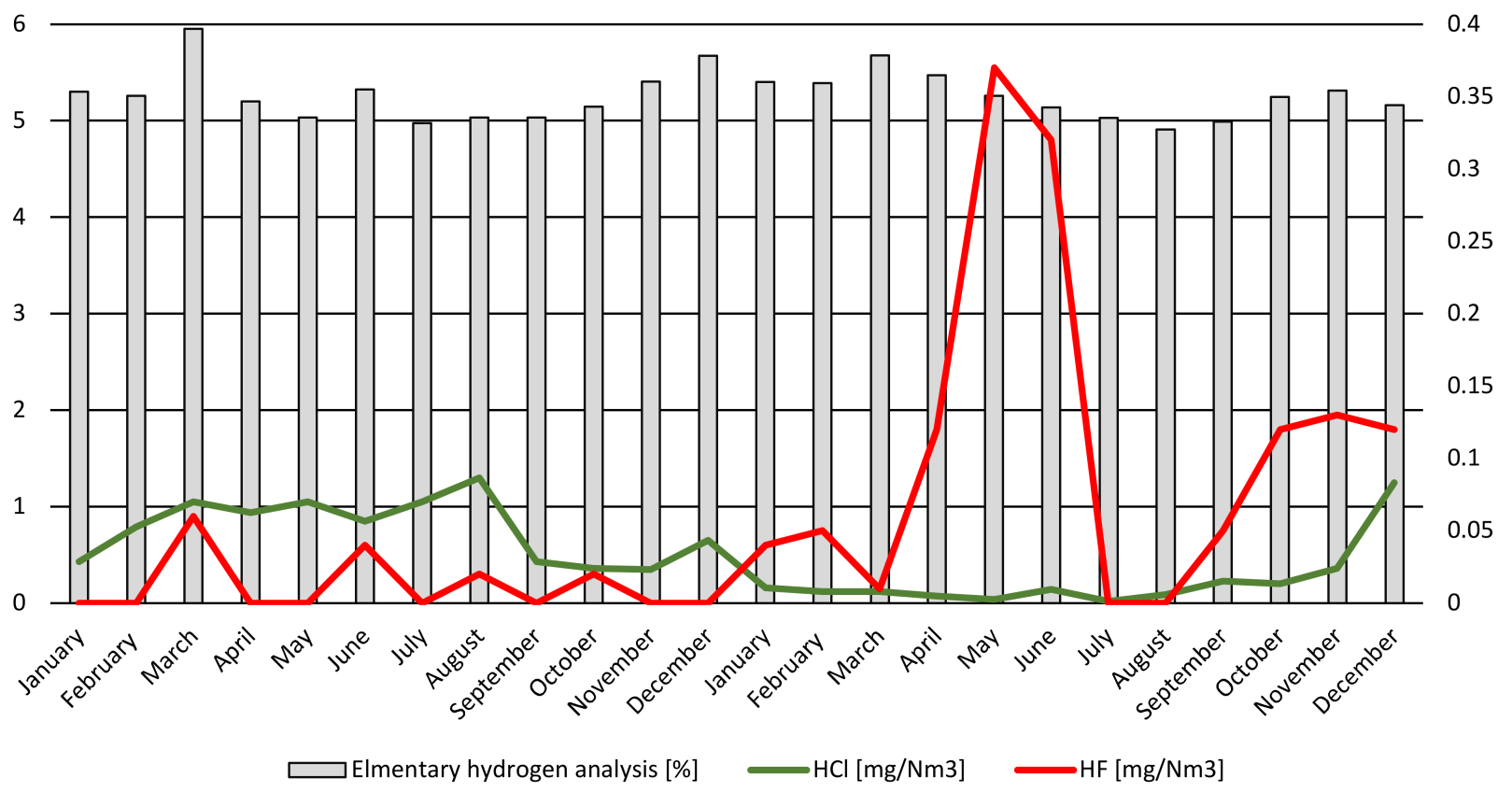

Figure 6. Relationship between hydrogen content in the sediment and the emission of hydrogen chloride and hydrogen fluoride. 
35
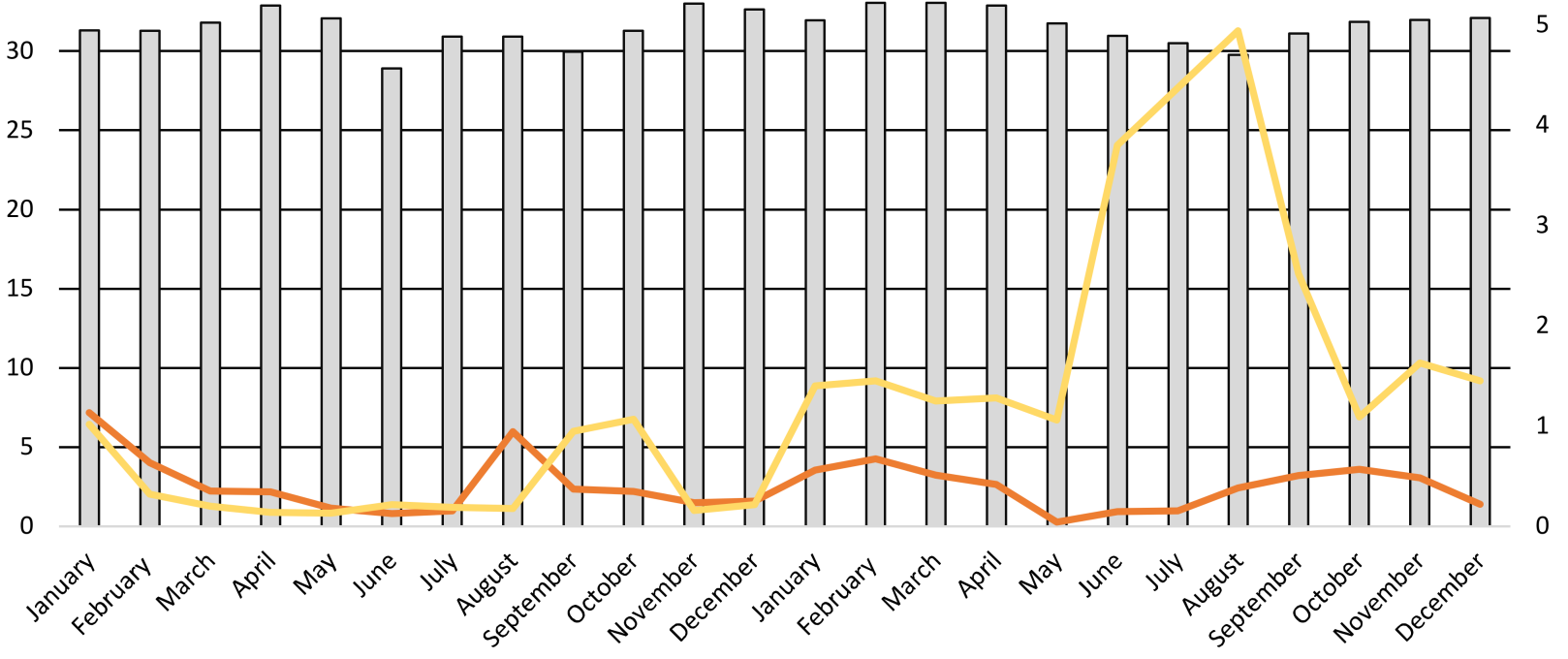

Elmentary carbon analysis [\%]

$\mathrm{CO}[\mathrm{mg} / \mathrm{Nm} 3]$

COT $[\mathrm{mg} / \mathrm{Nm} 3]$

Figure 7. Relation between the carbon content in the sediment and the emission of carbon monoxide, total organic carbon.

As can be seen in Figures 6 and 7, in the summer period in 2020 there was a sharp increase in the concentrations of HF and total COT (six times higher for HF and 20 times for COT) compared to the same period in 2019. It should be noted that the content of elements $\mathrm{C}$ and $\mathrm{H}$ in the sediment remained at the same level. The reason can be seen in the increased demand for additional fuel (light fuel oil), which is needed to maintain the proper temperature of the process.

Figures 8 and 9 present the course of variability in the pollution concentration for combustion lines No. 1 and No. 2. As can be seen, the concentration of HF remained at 0 . This observation confirms the reaction of the exhaust gas treatment system to increasing acidic pollution-i.e., to $\mathrm{SO}_{2}, \mathrm{HCl}$, and $\mathrm{HF}$. The system dispenses a reagent the moment pollution increases.

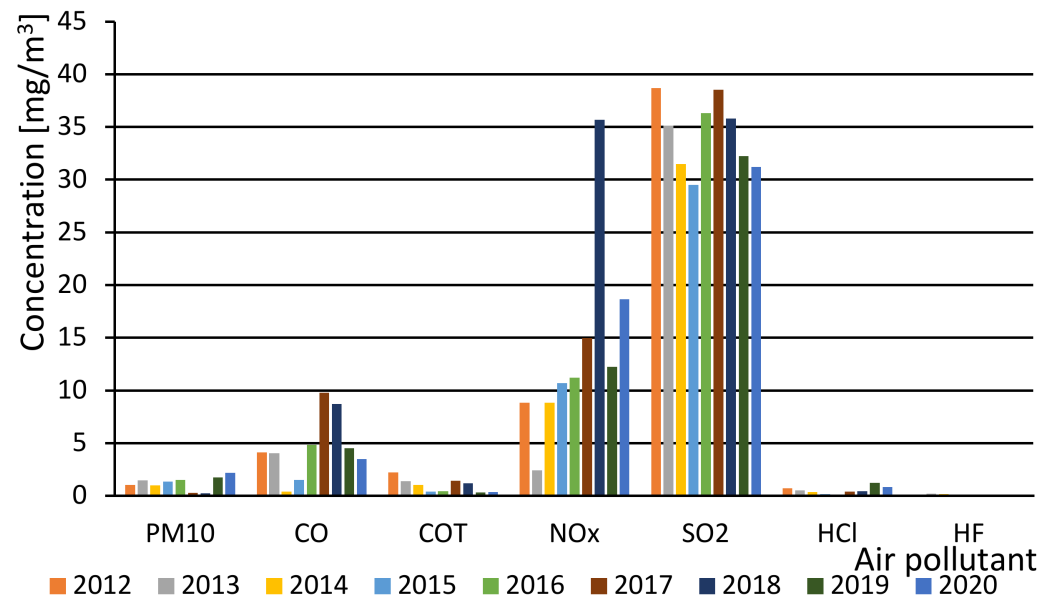

Figure 8. Concentration of pollution for combustion line No. 1. 


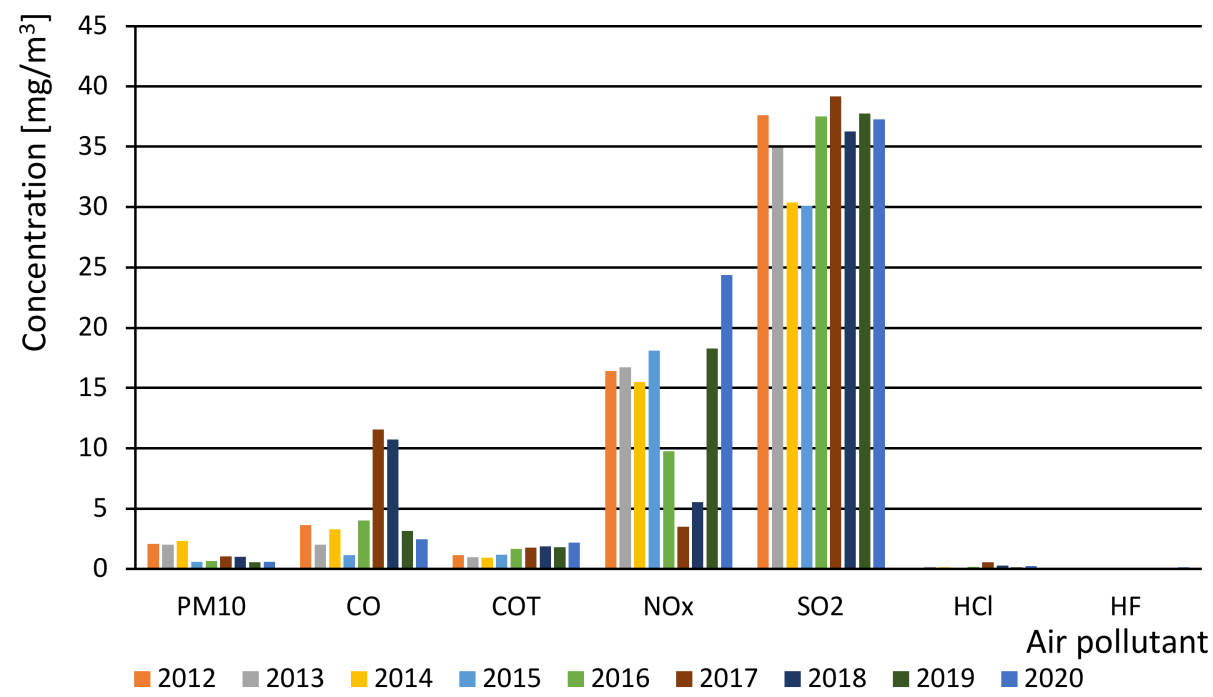

Figure 9. Concentration of pollution for combustion line No. 2.

The data shown in Figures 8 and 9 reveal clear differences in the pollution concentrations for the two combustion lines. The concentration of pollution, in particular $\mathrm{SO}_{2}$ and $\mathrm{NO}_{\mathrm{x}}$, increased in comparison with Period II in the case of combustion line No. 2. The concentration of $\mathrm{SO}_{2}$ increased by $20 \%$, and the concentration of $\mathrm{NO}_{\mathrm{x}}$ more than doubled. The pollution concentrations for combustion line No. 1 also increased, although not so significantly. Comparison of Periods II and III reveals that the concentration of $\mathrm{HCl}$ increased by $20 \%$, whereas the concentration of dust doubled in the two lines.

These results may be due to differences in the construction of the fluid bed furnaces themselves. Fluid bed furnaces have a refractory lining, handmade by a specialized team of workers. However, the lining may differ, depending on human factors on a specific day. The technology of making of such linings may also influence the parameters of operation. The duration for which the exhaust pipes are in the afterburner chamber may vary, and differences between the temperatures of the fluidized beds in the furnaces may occur. Line number 2 has higher combustion efficiency, which translates into more pollutants.

The differences between pollution concentrations are also influenced by the composition of dewatered digested sludge containing large amounts of detergent and compounds from disinfectants. Disinfectants can change the properties of sludge. These factors affect the efficiency of the combustion process, as can be seen in Figures 8 and 9. The differences are especially visible for $\mathrm{HF}, \mathrm{HCl}$, and COT. According to the literature, in 2020 sales of disinfectants increased by almost $20 \%$ compared to 2019 . Sales of antidepressants increased by $12 \%$.

The results of our analyses show the pandemic restrictions contributed to changes in the pollution emitted into the atmosphere. Therefore, we decided to concentrate only on Period II, before the COVID-19 pandemic, and on Period III, during the pandemic. The amounts of pollutants emitted from the systems of thermal treatment were also analyzed. The data included annual emissions of pollution into the atmosphere. The results are presented in Figures 10 and 11. 


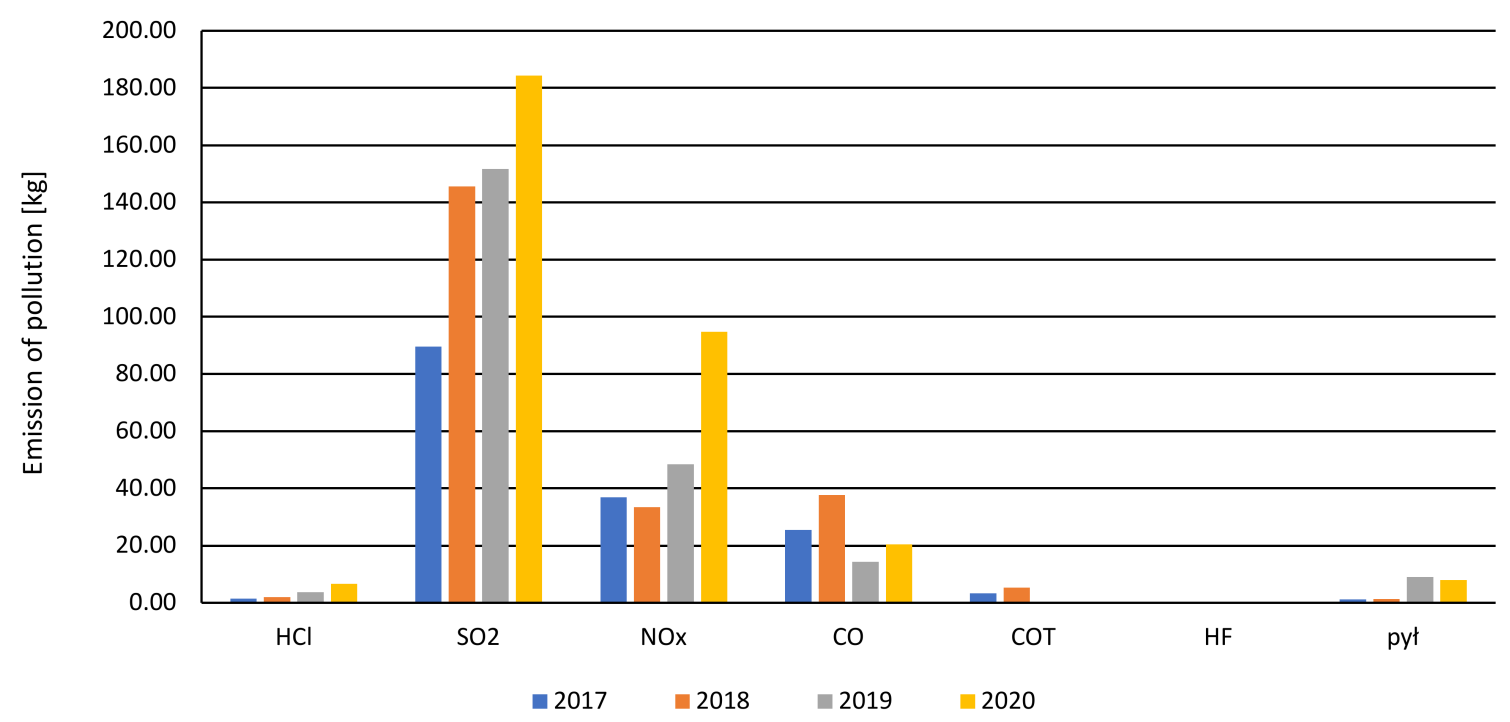

Figure 10. Mass of pollutants emitted into the atmosphere 2017-2020 from line No. 1.

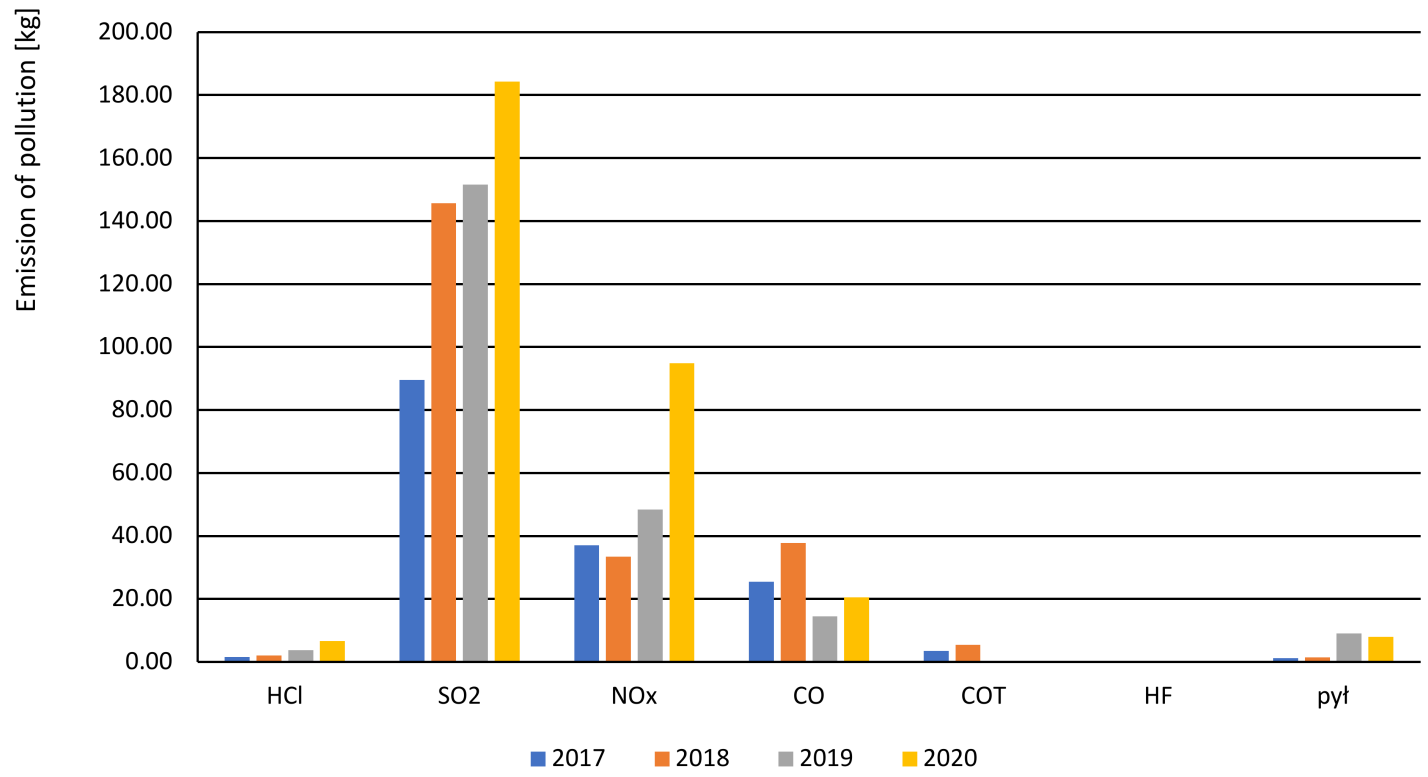

Figure 11. Mass of pollutants emitted into the atmosphere 2017-2020 from line No. 2.

\subsection{Emission of Pollutants}

Figure 10 shows the amounts of pollutants emitted from line No. 1 in the years 2017-2020. For the reasons explained in our discussions of Figures 8 and 9, hydrogen fluoride emissions into the atmosphere are 0 , because the amount of HF pollution was also 0 .

Overall, pollution emissions increased. The largest increase was observed for $\mathrm{SO}_{2}$ (by $48 \%$ compared to Period II) and NO (double compared to Period II). The emission of $\mathrm{HCl}$ also increased (fourfold compared to Period II). The reasons can be found in the increased concentration of sewage coming into the plant, which obviously caused changes in the composition of the sludge undergoing thermal treatment. The amounts of organic compounds in the sludge subjected to thermal conversion remained at 60-65\%.

We also compared the amounts of pollution emitted into the atmosphere with the amount of combusted MSS. The given quantities refer to dewatered fermented sludge with humidity content of approx. $80 \%$. The humidity of the sludge depends on the use of dewatering appliances. Lower humidity will eliminate the drying stage from the combustion process in the furnace chamber. 
The system operates on average about 10 months a year. During that time, it thermally disposes of about $80,000 \mathrm{mg}$ of dewatered fermented municipal sewage sludge. The data collected in 2017-2020 (Periods II and III) reveal that the amount of thermally processed sludge dropped. Nonetheless, the emission of pollution into the atmosphere increased. This relation is presented in Figure 12. In 2020, when the pandemic worsened, the quantity of combusted sludge was approx. $7 \%$ lower than in 2019, and approx. $9 \%$ lower than in 2018. Pollution for this period increased by approx. 3\% in relation to 2019 and by approx. $9 \%$ in relation to 2018 .

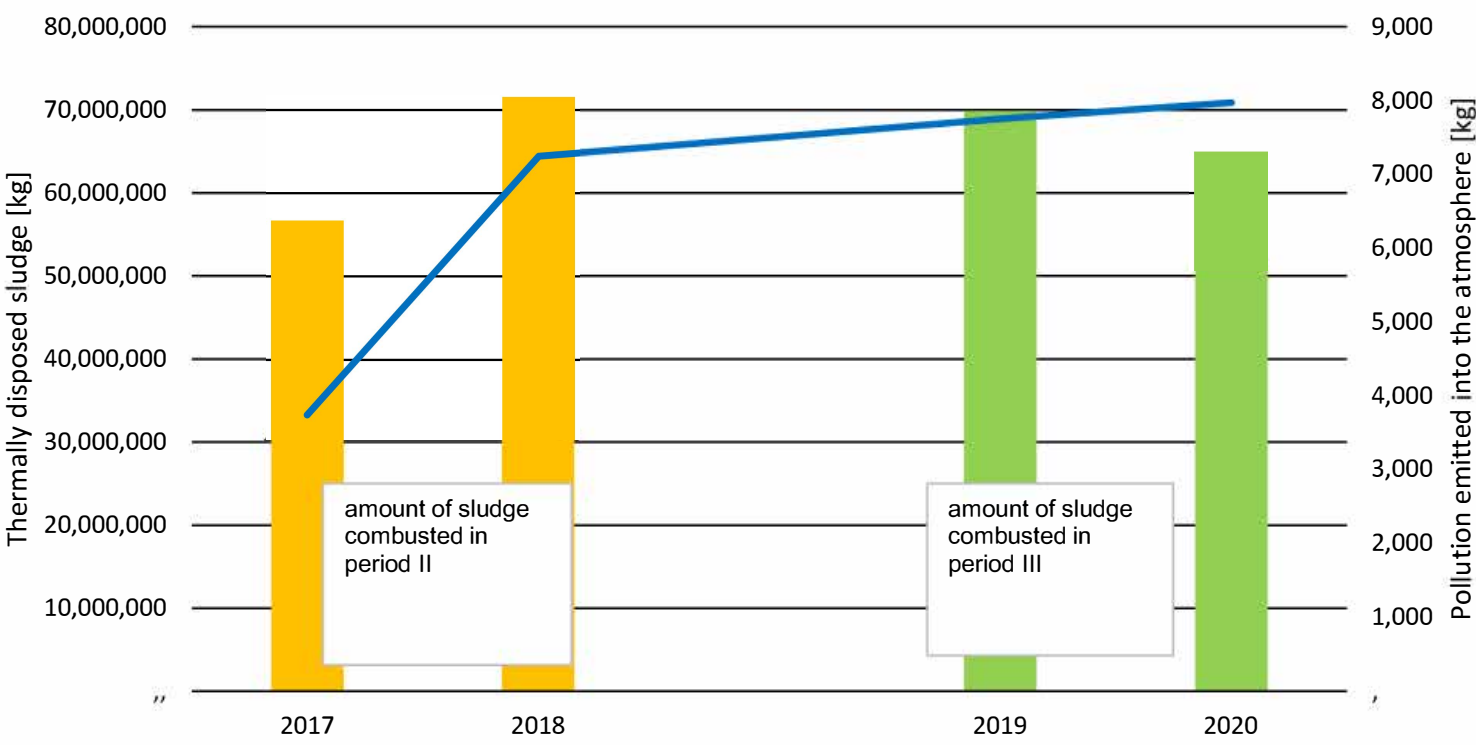

Figure 12. Pollution emissions relative to the amount of combusted sludge.

Subsequent analysis of the concentration of pollution in the proximity of the ITPO and examination of the level of background pollution indicated that the amount of pollution decreased, in some cases almost by half. Comparing 2017 from Period II and 2020 from Period III, $\mathrm{NO}_{2}$ decreased by $44 \%, \mathrm{SO}_{2}$ by $32 \%$, and PM10 dust by $33 \%$. These results can be associated with the increased interest in renewable energy resources and the outbreak of COVID-19, which caused changes in the lifestyles and behaviour of people living in the vicinity of the sewage treatment plant. In Period III, the plant operated with reduced staff (by almost $60 \%$ ). Figure 13 presents the pollution concentrations. The trending line is drawn to illustrate the course of changes in the pollution background.

In 2020, the $\mathrm{SO}_{2}$ concentration was higher than in 2019. The concentrations of pollution changed throughout the year (Figure 14). The highest values were noted in the winter months (between November and March, when temperatures in Poland drop below $0{ }^{\circ} \mathrm{C}$ ). In the summer period (between April and October) the concentrations were almost 50\% lower. Air quality standards are presented in Table 10.

Table 10. Air quality standards [46,47].

\begin{tabular}{cccc}
\hline Pollution & $\begin{array}{c}\text { Standards According } \\
\text { to WHO Guidelines } \\
{\left[\mu \mathrm{g} / \mathbf{m}^{3}\right]}\end{array}$ & $\begin{array}{c}\text { Standards According } \\
\text { to Directive } \\
(\mathbf{2 0 0 8 / 5 0 / C E )} \\
{\left[\mu \mathrm{g} / \mathbf{m}^{3}\right]}\end{array}$ & $\begin{array}{c}\text { Standards According } \\
\text { to Regulations } \\
\text { of the Minister of } \\
\text { the Environment } \\
{\left[\mu \mathrm{g} / \mathbf{m}^{3}\right]}\end{array}$ \\
\hline $\mathrm{NO}_{2}$ & 40 & 40 & 40 \\
$\mathrm{PM}^{3}$ & 20 & 40 & 40 \\
$\mathrm{SO}_{2}$ & 20 & 125 & 125 \\
\hline
\end{tabular}




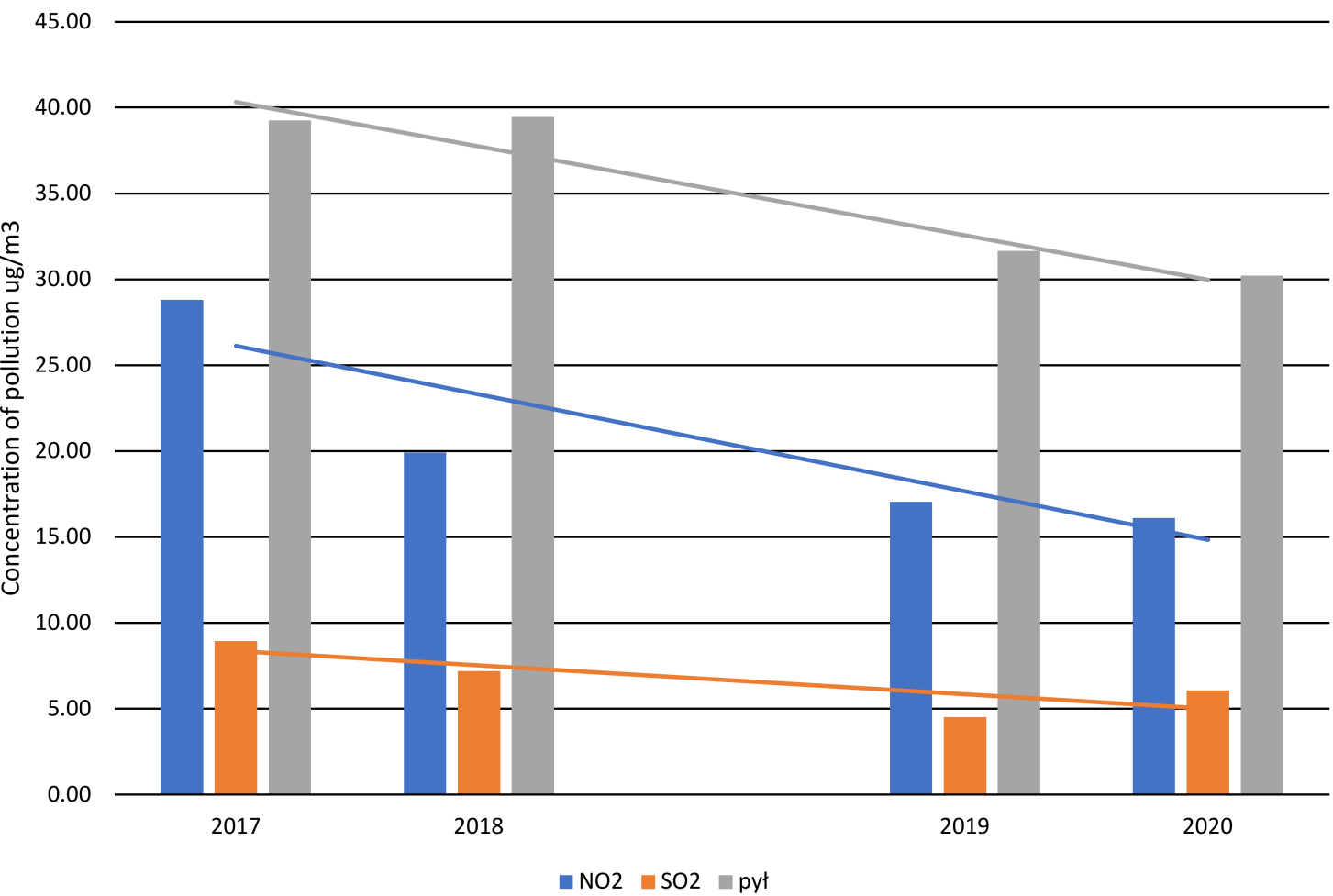

Figure 13. Changes in pollution concentrations relative to background levels.

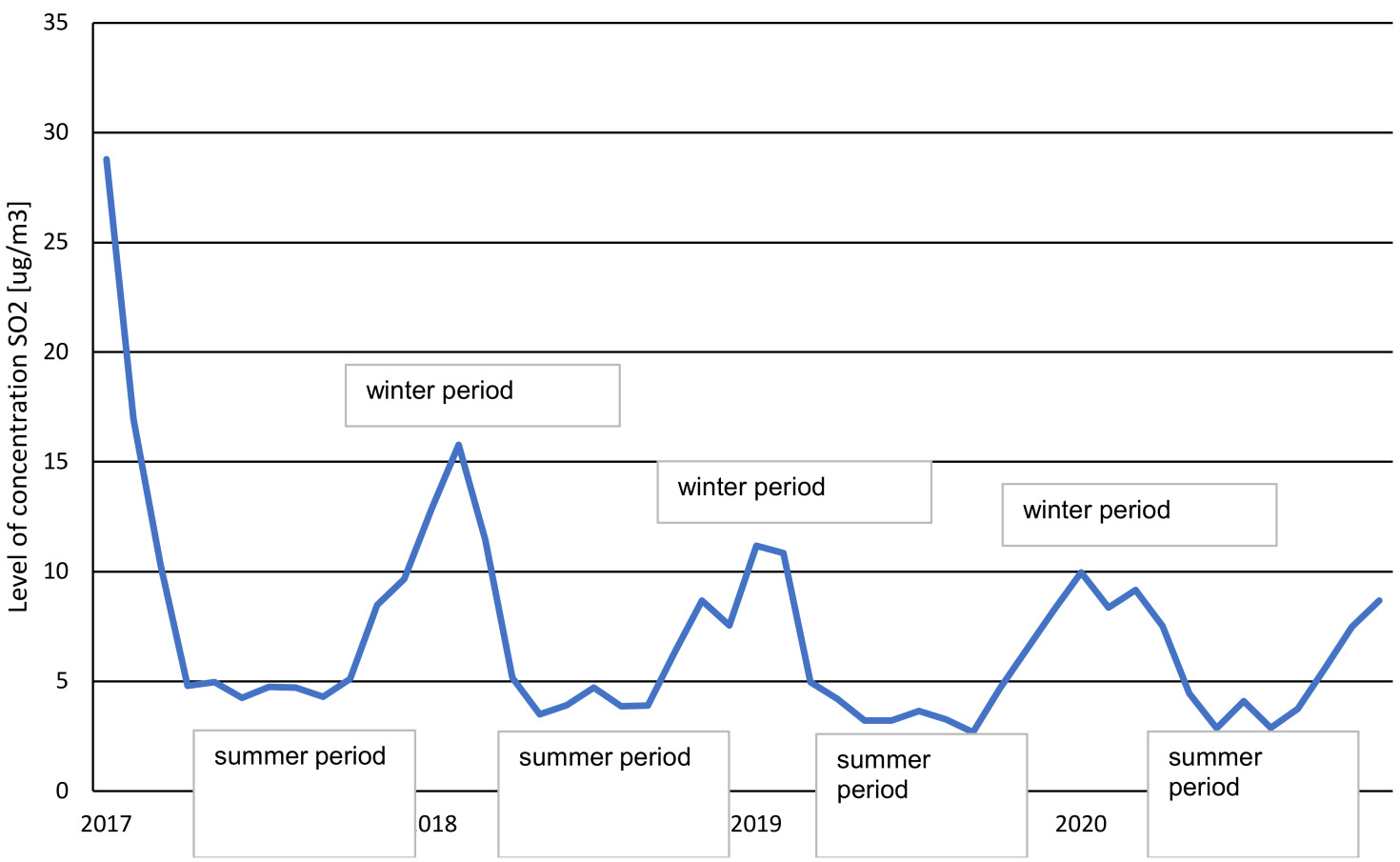

Figure 14. Course of background concentrations of $\mathrm{SO}_{2}$.

\subsection{Analysis of Biological Factors}

Microorganisms are present in all natural and anthropogenic environments. Although invisible to the naked eye, they should not be ignored, because they can affect human health Increases in mould, dust, and fungi can accompany the development and multiplication of microorganisms. Microorganisms can act as pathogens, causing respiratory diseases, sinusitis and conjunctivitis, allergies, skin lesions, headaches, even cancer [48], depending 
on the species of microorganism and its concentration in the inhaled air, the period of exposure to contamination, and individual immune reactions. The quality of inhaled air can also influence mental concentration and human wellbeing [49].

A list of biological factors was given in Directive (2000/54/EC) and transferred into state legislature in the form of Regulation of the Minister of Health of 22 April $2005 \mathrm{w}$ sprawie szkodliwych czynników biologicznych dla zdrowia w środowisku pracy oraz ochrony zdrowia pracowników zawodowo narażonych na te czynniki (on harmful biological factors for health in the working environment and on the health protection of workers professionally exposed to these factors) [50].

Measurements and analyses of biological factors have indicated the presence of actinomycetes, in the amount of approx. $10.5 \mathrm{cfu} / 1 \mathrm{~m}^{3}$ [37]. The presence of Staphylococcus mannitolo was also observed, in the amount of approx. $3.5 \mathrm{cfu} / \mathrm{m}^{3}$. Quantitative analysis revealed that the number of fungi dropped significantly after June 2020. Figure 15 shows the course of storage, as well as the presence of fungi in the area of GOS and in the vicinity of the ITPO. In 2019, there were increasing amounts of sludge deposited in the temporary storage area at the ITPO, which tripled by the end of the year. The hydration of the sludge was approx. $89 \%$. The significant amount of wet sludge caused an increase in the amounts of fungi released into the atmosphere. In the period 2019-2020, the dehydrated sludge was not incinerated and did not undergo natural air-drying. Therefore, the amount of fungi released into the atmosphere decreased [51]. The process of drying sludge begins at its surface and permeates deeper into the sludge. The crust formed on the top of the sludge covers the inner wet part and blocks the release of fungi.

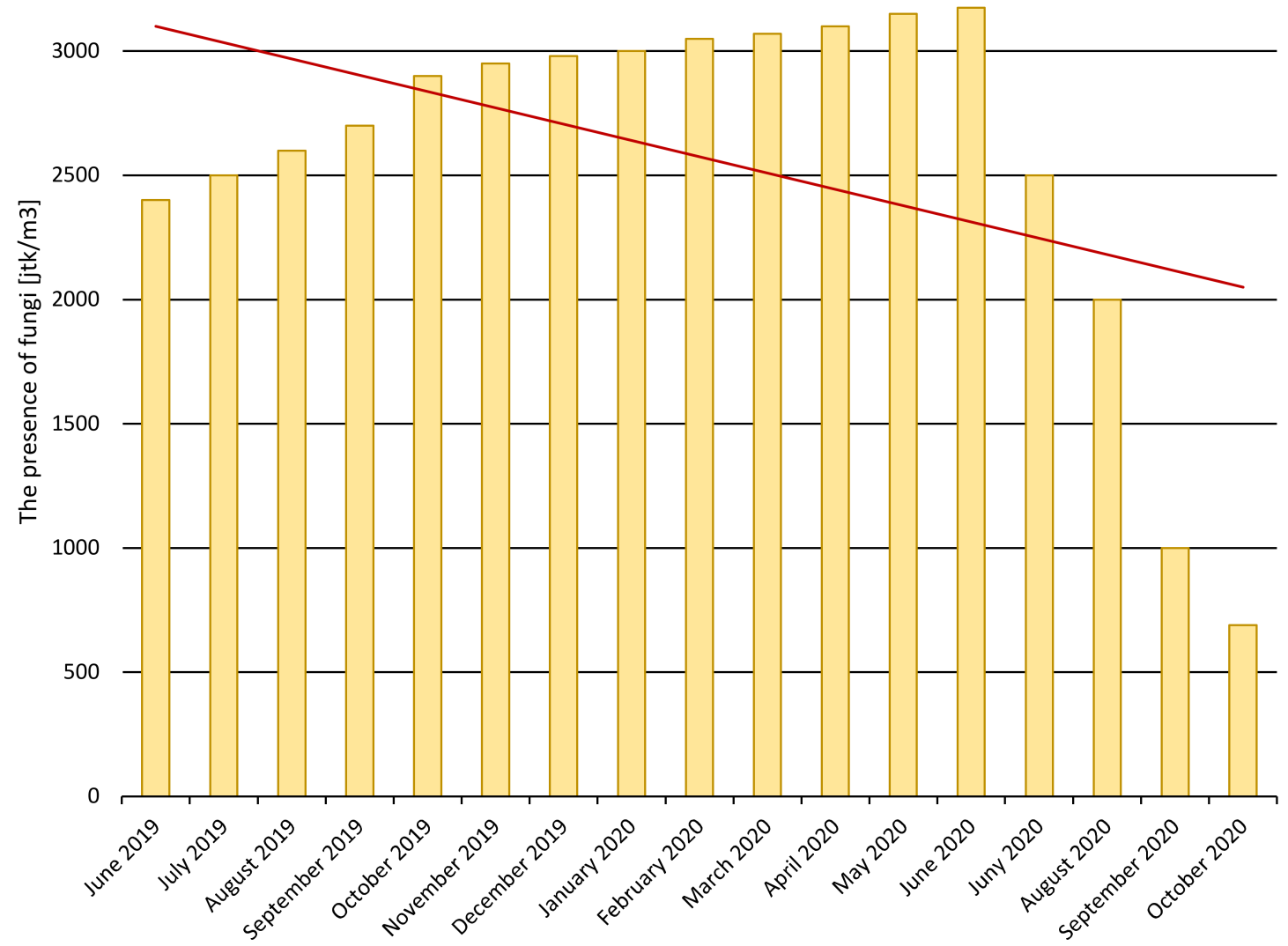

Figure 15. Amount of fungi in the GOŚ area. 


\section{Discussion}

The atmospheric air around a sewage treatment plant contains pollution characteristic for the type of installation. The air in the vicinity of objects associated with sewage sludge processing is especially affected. The staff of the plant as well as the local residents are particularly exposed. Research shows that the influence of a sewage treatment plant extends to a range of $3 \mathrm{~km}$ (Michalak, Pawlas 2012). The ailments most frequently reported by staff and residents of the surrounding areas are associated with the respiratory system. Various types of allergies (skin, inhalation allergies) and gastric disorders have also been reported [52]. Therefore, it is necessary to monitor the emission of pollution from thermal processing of MSS. Having analyzed the technological process from the perspective of emissions, it is possible to take suitable actions if the established limits for pollutants have been exceeded [21].

We studied the influence of fermented dehydrated sludge thermal processing on the quality of air in a sewage treatment plant and its vicinity. The operation of the thermal treatment system was found to have a negligible impact on the concentrations of chemical pollutants in the air. The data collected throughout our research indicate that no established limits for pollutants were exceeded, and that the pollutants had no influence on the level of background pollution, either on the premises or in the vicinity of the plant. The system also did not cause changes in the concentrations of pollutants in the area. Comparing concentrations of background pollution in Periods II and III, the concentration of $\mathrm{NO}_{2}$ decreased by $32 \%$, the concentration of $\mathrm{SO}_{2}$ decreased by $34 \%$, and concentration of dust PM10 decreased by $22 \%$. This applied to both chemical and biological agents.

The number of biological factors was also found to be insignificant and did not exceed the accepted standards. The average number of fungi in Period II equaled $2700 \mathrm{cfu} / \mathrm{m}^{3}$, and in Period III was $2000 \mathrm{cfu} / \mathrm{m}^{3}$. These values constitute $54 \%$ and $40 \%$ of the acceptable amounts of microorganisms specified in Directive (2000/54/CE), respectively. The presence of Escherichia coli and Staphylococcus haemolyticus was not detected. This absence should be considered positive, as it confirms the proper composition of atmospheric air around the ITPO area, which therefore has no negative impact on the rest of the sewage treatment plant or the neighboring areas.

Our analysis confirms the influence of the SARS-Cov-2 coronavirus pandemic on the concentration of pollution released into the atmosphere. This was not a direct effect, as no increase in either chemical or biological factors was found. Instead, the pandemic had an indirect effect, influenced by changes in society, behavior, and habits. The amount of background pollution dropped, and in 2020 reached its lowest level for several years. This situation was most probably the effect of the national lockdown, which halted mobility. This applied to modes of transportation (an airport, a county road, and industrial zones are located near the EIA), but also to the use of public spaces. Higher background $\mathrm{SO}_{2}$ concentrations were observed in 2020. The reason may be that people spent much more time in their homes, which therefore required more heating. The highest concentrations of background $\mathrm{SO}_{2}$ were noted during the so-called heating season, in winter, while the lowest levels were observed in summer [53]. The summer season was characterized by a background level of $\mathrm{SO}_{2}$ below 5 $\mu \mathrm{g} / \mathrm{m}^{3}$. The level decreased with each season. Among other factors, this may have been due to the low average annual precipitation ( $30 \%$ of the highest average annual precipitation in Poland), as well as to persistent temperatures above $30^{\circ} \mathrm{C}$.

We also observed that despite a decrease in the amount of thermally processed MSS, the amount of emitted pollution increased. This was the result of increasing concentrations of sewage pouring into the plant. During the pandemic period, there were increased levels of detergents and disinfectants released into wastewater, which affected the structure of the MSS. At the same time, the amount of sewage pouring into the plant decreased, which was associated with the economic situation (closed plants/industry, loss of jobs, etc.). 


\section{Conclusions}

The results of this study show that the system of thermal sludge treatment at the Group Sewage Treatment Plant in Łódź Itd. does not cause environmental pollution, and the standards set out in Directive (2015/2193/CE) are being met. No limits on chemical pollution (e.g., $\mathrm{SO}_{2}, \mathrm{NO}_{\mathrm{x}}$ ) or physical pollution (i.e., dust) were exceeded. The pollution levels were far below the established limits (for $\mathrm{SO}_{2} 26 \%$ below the standard, for $\mathrm{NO}_{x} 84 \%$ below the standard, for PM10 86\% below the standard) [54].

The sewage treatment plant itself does not affect the emission of pollutants. Our research shows that the sludge has a constant elemental composition, despite periodic variability related to the season. The treatment process and the subsequent production of municipal sewage sludge does not adversely affect the environment. However, it should be noted that MSS should be thermally transformed immediately to remove bacteria and viruses completely.

The analysis presented here can be also applied to other objects of this type-particularly in larger municipalities, where such systems are located in urban zones rather than in the outskirts. Our results suggest that the location of such facilities in urban ventilation corridors should not adversely affect the quality of atmospheric air in the urban centers. At the same time, it should be remembered that meteorological conditions determine the inflow of air into urban centres.

Author Contributions: Conceptualization, R.C. and J.W.; methodology, R.C., J.W.; software, J.W., R.C.; writing-original draft, R.C., J.W., review \& editing, R.C. All authors have read and agreed to the published version of the manuscript.

Funding: This research received no external funding.

Data Availability Statement: Data available on request.

Conflicts of Interest: The authors declare no conflict of interest.

\section{References}

1. Pohořelý, M.; Moško, J.; Zach, B.; Šyc, M.; Václavková, ̌̌.; Jeremiáš, M.; Svoboda, K.; Skoblia, S.; Beňo, Z.; Brynda, J.; et al. Materiálové a Energetické Využití Suchého Stabilizovaného Čistírenského Kalu-Výroba Biocharu Středně-Teplotní Pomalou Pyrolýzou. Waste Forum 2017, 83-90.

2. Milik, J.; Pasela, R.; Szymczak, M.; Chalamoński, M. Evaluation of the physico-chemical composition of sludge from municipal sewage treatment plant. Rocz. Ochr. Srodowiska 2016, 18, 579-590.

3. Bień, J.B.; Wystalska, K. Przekształcanie Osadów Ściekowych w Procesach Termicznych; Wydawnictwo Seidel-Przywecki: Warszawa, Poland, 2009.

4. Bień, J.; Neczaj, E.; Worwag, M.; Grosser, A.; Nowak, D.; Milczarek, M.; Janik, M. Directions of sludge management in Poland after 2013. Inżynieria i Ochrona Środowiska 2011, 14, 375-384.

5. Watts, J.; Kommenda, N. Coronavirus Pandemic Leading to Huge Drop in Air Pollution. The Guardian. 2020. Available online: https:/ / www.theguardian.com/environment/2020/mar/23/coronavirus-pandemic-leading-to-huge-drop-in-air-pollution (accessed on 30 December 2020).

6. Cichowicz, R.; Wielgosiński, G. Analysis of Variations in Air Pollution Fields in Selected Cities in Poland and Germany. Ecol. Chem. Eng. S 2018, 25, 217-227. [CrossRef]

7. Bourtsalas, A.C.; Huang, Q.; Zhang, H.; Themelis, N.J. Energy recovery in China from solid wastes by the moving grate and circulating fluidized bed technologies. Waste Dispos. Sustain. Energy 2020, 2, 27-36. [CrossRef]

8. Niesler, J.; Nadziakiewicz, J. Evaluating possibilities for co-combustion of municipal waste and sewage sludge in the Silesian agglomeration. Inżynieria Sr. 2013, 9, 29-41.

9. Henclik, A.; Kulczycka, J.; Gorazda, K.; Wzorek, Z. Uwarunkowania gospodarki osadami ściekowymi w Polsce i Niemczech. Inżynieria I Ochr. Sr. 2014, 17, 185-197.

10. Szymański, D.; Sikorski, W. Spalarnie Odpadów na Świecie. Available online: www.portalkomunalny.pl (accessed on 15 December 2021).

11. Szruba, M. Zagospodarowanie Osadów Ściekowych; Nowoczesne Budownictwo Inżynieryjne: Kraków, Poland, 2015; pp. 54-59. Available online: www.bibliotekanauki.pl/articles/364983 (accessed on 15 December 2021).

12. Arthurson, V. Proper Sanitization of Sewage Sludge: A Critical Issue for a Sustainable Society. Appl. Environ. Microbiol. 2008, 74, 5267-5275. [CrossRef] 
13. Bianchini, A.; Bonfiglioli, L.; Pellegrini, M.; Saccani, C. Sewage sludge drying process integration with a waste-to-energy power plant. Waste Manag. 2015, 42, 159-165. [CrossRef]

14. Fytili, D.; Zabaniotou, A. Utilization of sewage sludge in EU application of old and new methods-A review. Renew. Sustain. Energy Rev. 2008, 12, 116-140. [CrossRef]

15. Dai, J.; Xu, M.; Chen, J.; Yang, X.; Ke, Z. PCDD/F, PAH and heavy metals in the sewage sludge from six wastewater treatment plants in Beijing, China. Chemosphere 2006, 66, 353-361. [CrossRef] [PubMed]

16. Panepinto, D.; Genon, G. Wastewater sewage sludge: The thermal treatment solution. WIT Trans. Ecol. Environ. 2014, 180. [CrossRef]

17. Strauch, D. Microbiological Treatment of Municipal Sewage Sludge and Refuse as Means of Disinfection Prior to Recycling in Agriculture. Stud. Environ. Sci. 1991, 42, 121-136. [CrossRef]

18. Svoboda, K.; Hartman, M.; Syc, M.; Pohořelý, M.; Kameníková, P.; Jeremiáš, M.; Durda, T. Possibilities of mercury removal in the dry flue gas cleaning lines of solid waste incineration units. J. Environ. Manag. 2016, 166, 499-511. [CrossRef]

19. Cichowicz, R.; Stelegowski, A. The PMV and PPD indices in the selected boiler room. E3S Web Conf. 2018, 44, 00021. [CrossRef]

20. Cichowicz, R.; Stelegowski, A.; Pacak, A. The distribution of air temperature and velocity in the selected boiler room. E3S Web Conf. 2018, 44, 00020. [CrossRef]

21. Wielgosiński, G.; Cichowicz, R.; Wiśniewski, J. Ammonia Emission from Sewage Sludge Incineration Process. Ecol. Chem. Eng. S 2016, 23, 665-675. [CrossRef]

22. Wielgosiński, G. Thermal Treatment of Municipal Waste-Selected Issues (Termiczne Przekształcanie Odpadów Komunalnych-Wybrane Zagadnienia; Nowa Energia: Racibórz, Poland, 2016.

23. Carmen, A.M.; Domingoa, A.I.; Domingoa, H.; Corbela, J. Monitoring internal exposure to metals and organic substances in workers at a hazardous waste incinerator after 3 years of operation. Toxicol. Lett. 2003, 146, 83-91. [CrossRef]

24. Shih, T.S.; Chen, H.L.; Wu, Y.L.; Lin, Y.C.; Lee, C.C. Exposure assessment of polychlorinated dibenzo-p-dioxins and dibenzofurans (PCDD/Fs) in temporary municipal-waste-incinerator maintenance workers before and after annual maintenance. Chemosphere 2006, 64, 1444-1449. [CrossRef]

25. Pohorely, M.; Svoboda, K.; Trnka, O.; Baxter, D.; Hartman, M. Gaseous Emissions from the Fluidized-Bed Incineration of Sewage Sludge. Chem. Pap. 2005, 59, 458-463.

26. Lu, S.; Yang, L.; Zhou, F.; Wang, F.; Yan, J.; Li, X.; Chi, Y.; Cen, K. Atmospheric emission characterization of a novel sludge drying and co-combustion system. J. Environ. Sci. 2013, 25, 2088-2092. [CrossRef]

27. Ding, W.; Li, L.; Liu, J. Investigation of the effects of temperature and sludge characteristics on odors and VOC emissions during the drying process of sewage sludge. Water Sci. Technol. 2015, 72, 543-552. [CrossRef] [PubMed]

28. European Union law. Available online: https:// eur-lex.europa.eu/legal-content/PL/TXT/HTML/?uri=OJ:C:2018:124:FULL\& from $=$ CS (accessed on 15 December 2021).

29. Ustawa z dnia 14 grudnia 2012 r o odpadach.European Legislation Identifier. Available online: www.eli.gov.pl (accessed on 15 December 2021).

30. Rozporządzenie Ministra Klimatu w sprawie katalogu odpadów, European Legislation Identifier. Available online: www.eli.gov.pl (accessed on 15 December 2021).

31. Wiśniewski, J. Non-Catalytic Autoreduction of Nitrogen Oxides during Combustion of Municipal Sewage Sludge (Niekatalityczna Autoredukcja Tlenków Azotu Podczas Spalania Komunalnych Osadów Ściekowych). Ph.D. Thesis, Lodz University of Technology, Lodz, Poland, 2019.

32. Biuletyn Monitoringu Klimatu Polski. Available online: www.klimat.imgw.pl (accessed on 1 December 2021).

33. Institute of Meteorology and Water Management, National Research Institute Poland. Available online: www.imgw.pl (accessed on 1 December 2021).

34. Procyk, G.; Helbig, A. Annual Assessment of the Impact of Equipment and Technological Processes of the Group Sewage Treatment Plant in Łódź on the State of Ambient Air Pollution; Annual Report for 2012; SGS Eko-Projekt Sp. z o.o.: Pszczyna, Poland, 2013.

35. Horodecka, N.; Helbig, A. Annual Assessment of the Impact of Equipment and Technological Processes of the Group Sewage Treatment Plant in Łódź on the State of Ambient Air Pollution; Annual Report for 2013; SGS Eko-Projekt Sp. z o.o.: Pszczyna, Poland, 2014.

36. Skwarska, A.; Horodecka, N. Annual Assessment of the Impact of Equipment and Technological Processes of the Group Sewage Treatment Plant in Łódź on the State of Ambient Air Pollution; Annual Report for 2015; SGS Eko-Projekt Sp. z o.o.: Pszczyna, Poland, 2016.

37. SGS Eko-Projekt Annual Assessment of the Impact of Equipment and Technological Processes of the Group Sewage Treatment Plant in Łódź on the State of Ambient Air Pollution; Annual Report for 2014; SGS Eko-Projekt Sp. z o.o.: Pszczyna, Poland, 2015.

38. Cichowicz, R.; Stelegowski, A. Average Hourly Concentrations of Air Contaminants in Selected Urban, Town, and Rural Sites. Arch. Environ. Contam. Toxicol. 2019, 77, 197-213. [CrossRef] [PubMed]

39. Niazi, S.; Hassanvand, M.S.; Mahvi, A.H.; Nabizadeh, R.; Alimohammadi, M.; Nabavi, S.; Faridi, S.; Dehghani, A.; Hoseini, M.; Moradi-Joo, M.; et al. Assessment of bioaerosol contamination (bacteria and fungi) in the largest urban wastewater treatment plant in the Middle East. Environ. Sci. Pollut. Res. 2015, 22, 16014-16021. [CrossRef] [PubMed]

40. MAS-100 NT. Available online: https://www.merckmillipore.com/PL/pl/product/Air-sampler-System-MAS-100NT,MDA_ CHEM-109191?ReferrerURL=https\%3A\%2F\%2Fwww.bing.com\%2F (accessed on 5 December 2021).

41. Kestrel 3500-Anemometr. Available online: https://www.label.pl/po/anemometr-k3500.html (accessed on 15 December 2021). 
42. PN-EN 13098:2020-01. Narażenie na Stanowiskach Pracy-Pomiar Mikroorganizmów i Produktów Pochodzenia Drobnoustrojowego Zawieszonych w Powietrzu-Wymagania Ogólne. Available online: www.pkn.pl (accessed on 5 December 2021).

43. PN-Z-04111-02:1989. Ochrona Czystości Powietrza-Badania Mikrobiologiczne-Oznakowanie Liczby Bakterii w Powietrzu Atmosferycznym (Imisja) Przy Pobieraniu Próbek Metodą Aspiracyjną I Sedymentacyjną. Available online: https://sklep.pkn. $\mathrm{pl} / \mathrm{pn}-\mathrm{z}-04111-02-1989 \mathrm{p} . \mathrm{html}$ (accessed on 5 December 2021).

44. PN-Z-04111-03:1989. Ochrona Czystości Powietrza-Badania Mikrobiologiczne-Oznakowanie Liczby Grzybów Mikroskopowych w Powietrzu Atmosferycznym (Imisja) Przy Pobieraniu Próbek Metodą Aspiracyjną i Sedymentacyjną. Available online: https://sklep.pkn.pl/pn-z-04111-03-1989p.html (accessed on 5 December 2021).

45. Dz.U. $2001 \mathrm{nr} 62$ poz. 627. Available online: http:/ / isap.sejm.gov.pl/isap.nsf/DocDetails.xsp?id=WDU20010620627 (accessed on 5 December 2021).

46. World Health Organization (regional office for Europe). Available online: www.euro.who.int (accessed on 10 December 2021).

47. Dz.U. 2012 poz. 1031. Available online: http:// isap.sejm.gov.pl/isap.nsf/DocDetails.xsp?id=WDU20120001031 (accessed on 5 December 2021).

48. Podkowik, M.; Bania, J.; Schubert, J.; Bystroń, J. Gronkowce Koagulazo-Ujemne: Nowe Zagrożenie dla Zdrowia Publicznego? Available online: https:/ / www.vetpol.org.pl/dmdocuments/ZW-2014-01-11.pdf (accessed on 5 December 2021).

49. Prędecka, A.; Kosut, S. Analiza Zagrożeń Mikrobiologicznych w Powietrzu Wewnętrznym na Przykładzie Zanieczyszczeń w Wybranych Pomieszczeniach Szkoły Głównej Służby Pożarniczej. Available online: https://kursy-szkolenia.sgsp.edu.pl/ Download/WYDAWNICTWO/CZYTELNIA/ZN_62_tom\%201.pdf (accessed on 5 December 2021).

50. Dz.U. $2005 \mathrm{nr} 81$ poz. 716. Available online: http:/ / isap.sejm.gov.pl/isap.nsf/DocDetails.xsp?id=WDU20050810716 (accessed on 5 December 2021).

51. Liu, Y.; Zhang, Y.; Shi, Y.; Shen, F.; Yang, Y.; Wang, M.; Zhang, G.; Deng, T.; Lai, S. Characterization of fungal aerosol in a landfill and an incineration plants in Guangzhou, Southern China: The link to potential impacts. Sci. Total Environ. 2020, 764, 142908. [CrossRef] [PubMed]

52. Michalak, A.; Pawlas, K. Influence of biological aerosol from wastewater treatment plants on workers and the local residents health-literature review Medycyna Środowiskowa. Environ. Med. 2012, 15, 116-122.

53. Wielgosiński, G.; Czerwińska, J.; Namiecińska, O.; Cichowicz, R. Smog episodes in the Lodz agglomeration in the years 2014-17. E3S Web Conf. 2018, 28, 01039. [CrossRef]

54. Bo, X.; Guo, J.; Wan, R.; Jia, Y.; Yang, Z.; Lu, Y.; Wei, M. Characteristics, correlations and health risks of PCDD/Fs and heavy metals in surface soil near municipal solid waste incineration plants in Southwest China. Environ. Pollut. 2022, $298,118816$. [CrossRef] 